\title{
How Regions React to Recessions: Resilience and The Role of Economic Structure
}

\author{
Ron Martin*, Peter Sunley**, Ben Gardiner ${ }^{* * *}$ and Peter Tyler****
}

*Department of Geography, University of Cambridge Downing Place, Cambridge CB2 $3 \mathrm{EN}, \mathrm{UK}$

Email: rlm1@cam.ac.uk

**School of Geography and the Environment, University of Southampton, Highfield, Southampton

Email: P.J. Sunley@soton.ac.uk

${ }^{* * *}$ Cambridge Econometrics and Department of Geography, University of Cambridge, Downing Place, Cambridge CB2 3EN, UK

Email: bg@camecon.com

****Department of Land Economy, University of Cambridge, Silver Street, Cambridge CB3 9EP

Email: pt23@cam.ac.uk

Second Revised Version December 2015 


\begin{abstract}
This paper examines how employment in the major UK regions has reacted to the four major recessions of the last forty years, namely 1974-67, 1979-83, 1990-93 and 2008-10. The notions of resistance and recoverability are used to examine these reactions. The analysis reveals both continuities and significant changes in the regional impact of recession from one economic cycle to the next. Further, while economic structure is found to have exerted some influence on the resistance and recoverability of certain regions, in general 'region-specific' or 'competitiveness' effects appear to have played an equally, if not more, significant role.
\end{abstract}

Keywords: Recessions Economic cycles Resistance Recoverability Regions Economic structure

JEL classification: R11 R12 E32

\title{
Acknowledgments:
}

The research for this paper formed part of a larger project on How Regions React to Recession: Resilience, Hysteresis and Long Run Impacts, funded by the UK Economic and Social Research Council (Grant ES/1035811/1), whose support is gratefully acknowledged. A version of the paper was presented at the Regional Studies Association Winter Conference, November 2014. The various comments made on those occasions, together with those of three anonymous referees, proved most useful in shaping the final version of the paper. 
Although the death of the business cycle has been frequently proclaimed in the post-Keynesian era, there are grounds for thinking that, like Mark Twain's obituary notice, such claims are a little premature (Peter Haggett, 1971).

Even now, many economists still think of recessions as a minor issue, their study as a faintly disreputable subject; the trendy work has all been concerned with technological progress and long-run growth. These are fine, important questions, and in the long run they are what really matter - but as Keynes pointed out, in the long run we are all dead (Paul Krugman, 1996).

\section{Introduction}

Interest in regional business cycles and regional economic fluctuations has a long history. The first systematic analyses were those of Vining and Neff in the 1940s (Vining, 1945, 1946a, 1946b; Neff, 1949). Important studies by other economists then followed in the 1960 s and 1970s, including classics by Borts (1960), Brechling (1967), Harris and Thirlwall, (1968) and Van Duijn (1973) (for a detailed survey, see Domazlicky, 1980). Attention focused on the sensitivity of regions to the business cycle, on the degree of synchronicity (leads and lags) of business cycles across regions, and on identifying the sources of regional variations in sensitivity and timing, especially the role of industrial structure and diversity (Conroy, 1975). Research into such issues typically drew on ideas from Keynesian business cycle theory and export base theory. During this period, and particularly in the 1970s, economic geographers also directed attention to the topic, mainly inspired by and drawing on Brechling's work (for example, Bassett and Haggett, 1971; Haggett, 1971; Jeffrey, Cassetti and King, 1964; Jeffrey, 1974). After the late-1970s, however, research on the subject within economic geography waned, as the focus shifted away from business cycles to regional production networks, regional agglomeration processes, regional innovation systems, regional competitiveness and a host of other issues concerned with uneven regional development.

But in the past few years, interest in regional business cycles and fluctuations has resurfaced, though mainly amongst economists rather than amongst economic geographers. The overwhelming focus of this more recent stream of work has been on the degree of synchronicity of regional business cycles, that is on the degree of co-movement of regional time paths of economic activity, where those time paths contain both trends and cycles. Some papers have concentrated on statistically identifying the relative contribution of common (national) and region-specific components to regional differences in economic cyclicity (for example, Carlino and Sill, 1996, 1997; Clark, 1998; Clark and Shin, 2000; Artis et al, 2009). Others have focused on developing time series and statistical methods for isolating trend and cyclical components and analysing their interaction (such as Harding and Pagan, 2002; Zarnowitz and Ozyildirim, 2006). Several others have been mainly concerned with assessing changes in the synchronicity of regional business cycles over time (for example, Owyang et al, 2005; Tondl and Traistaru-Siedschlag, 2006; 
Montoya and De Haan, 2008: Hayashida, and Hewings, 2009; Panteladis and Tsiapa, 2011; Bierbaumer-Polly, 2012). Yet others have examined the implication of asymmetries in regional business cycles for monetary integration and common currency areas (Bayoumi and Eichengreen, 1993; Krugman, 1993; Frankel and Rose, 1998; Barrios, Brülhart, Eliot and Sensier, 2003; Barrios and Lucio, 2003; Partridge and Rickman, 2005).

How far this revived interest in regional business cycles has been due to the impress of external economic circumstances is difficult to gauge, particularly as there is some debate over whether and to what extent economic fluctuations have become more or less pronounced over the past thirty years or so. Several claims were made in the early2000 s that since the early-1980s the volatility of the US economy had become much attenuated, eliciting the moniker of the 'great moderation' (the term coined by Stock and Watson, 2002, 2003). However, such studies typically look at the year on year variability in economic growth rates, which is not the same thing as comparing the severity of successive recessions. In the case of the UK, since the early-1970s, when the so-called long post-war 'golden age' of relatively stable growth and mild economic cycles came to an end, the economy has been subject to a succession of sharp recessions, much deeper than those in preceding post-war period. The warning issued by Haggett in 1971 (in the quote above) turned out to be highly prescient. With the recessionary contractions of the mid-1970s, and especially those of the early-1980s and the early-1990s, the economic cycle returned with a vengeance. Then the 'long boom' from the early-1990s into the late-20oos seemed to herald another 'golden age' free of major recessionary disruption, a sort of 'great moderation' to parallel that claimed for the US economy, and was interpreted as such by many UK economic and political observers. ${ }^{1}$ However, as we now know, in the UK as in the USA, and elsewhere, the boom of the 1990 s and 2000 s turned out to be unsustainable and unstable, and was brought emphatically to an end in 2008 by the financial crisis which then triggered the worst cyclical contraction in output since the Great Depression of the early-1930s. This time it was Paul Krugman who proved to be prophetic: on several occasions in the mid- to late-1990s he had pointed to various warning signs of impending economic turmoil, even as the apparent 'boom' in Western economies was gathering pace. ${ }^{2}$ For the UK, the 2008-2010 recession marked the latest in a series of contractions of historically significant amplitude.

How deep recessions impact across regions (and cities) within nations is an important issue. After all, the depth of a national recession, and the speed of recovery from it, are but reflections of the contractions and recoveries in the individual regional and

\footnotetext{
1 For example, in his speech to the Labour Party Conference in 2004, the British Chancellor of the Exchequer, Gordon Brown, was moved to proclaim that Britain was "no longer the boom-bust economy". The acronym NICE (non-inflationary continuous expansion) became common parlance to describe the performance of the UK economy in that period.

2 Not just in the quote in the beginning of this paper, but also, for example, in his Return of Depression Economics (Krugman, 1999).
} 
local economies of which the national economy is composed. But more than this, not only may regional variations in the depth of recessionary contraction create spatial inequalities in the negative consequences for employment, household incomes and welfare, there is the possibility that such effects may not be merely transitory, to be eliminated during the subsequent recovery phase, but prove to have longer-lasting repercussions. To use the phrase invoked by Cross, McNamara and Pokrovskii (2009), the 'memory of recession' (or 'remanence') may linger much longer in some regions than in others. Or to put it more formally, regions may have different degrees of resilience to recessions in the sense that regional economies possess different abilities for recovery, and in some cases recessions may have permanent or hysteretic effects on a region's growth path. Thus a region that experiences a particularly severe contraction of its economy during a recession may not necessarily 'rebound' or return to its pre-recession growth trajectory, but emerge on a lower or inferior growth path: recessions may shape regions' long-run growth rates, and thereby influence patterns of long run regional economic convergence or divergence (Martin, 2012, 2015; Martin and Sunley, 2015). In short, recessions and recoveries may not be events that simply take place 'around' autonomous long-term regional growth and development paths: they may shape and be part of those paths. Indeed, one way of viewing long-run regional growth is as a succession of phases of contraction and expansion, with turning points defined as 'peaks' and 'troughs' in activity (the terms used by Burns and Mitchell, 1946, in their classic work on business cycles).3

Given these considerations, our aim in this paper is examine the geographies of the past four economic cycles across the principal regions of the UK. To do this we construct simple measures of regional resistance to, and recovery from, successive recessions in order to analyse whether and in what ways regions have varied in their behavior from one economic cycle to the next. Our particular focus is on the influence of industrial structure on the resilience of UK regions to these recessions. There is a view, both in studies of regional business cycles and in more recent work on regional resilience (and indeed on regional growth more generally), that industrial structure plays a formative role in explaining regional differences in economic performance. This is an intriguing issue, especially when, as here, a number of successive recessions are under investigation, since regional industrial structures themselves change and evolve over time.

\section{The Resilience of Regions to Economic Recessions: Clarifying Concepts}

There is no single agreed approach to analysing regional reactions to economic cycles, construed as comprising recessionary contractions or shocks and subsequent recoveries or expansions. Several different perspectives can be identified. A common

\footnotetext{
3 In this sense, Krugman's seeming acceptance of a clear distinction, in the quote at the head of this paper, between economic cycles and long-run growth may not, in fact, be correct.
} 
approach in the contemporary literature on business cycles is to isolate 'cyclical' movements by first detrending the data, for example using some form of band-pass filter (for an example, see Partridge and Rickman, 2005). One problem with most such studies, however, is that statistical trend-cycle decompositions make no distinction between business cycles and growth cycles, and because they often involve smoothing the time series in question they can give misleading estimates of cyclical intensities and turning points (Zarnowitz and Ozyildirim, 2006). A different approach is to assume that economic cycles present movements around some long-run 'equilibrium' time path, and then use time series error-correction models to estimate both the long-run 'equilibrium' path and the speed of adjustment to cyclical shocks that move the system away from that path (see Fingleton, Garretsen and Martin, 2012). Yet another approach is to use an explanatory structural (causal) model to produce counterfactual paths against which the impact of cyclical disturbances can be estimated (for an example, see Fingleton, Garretsen and Martin, 2015). Others have suggested that recessionary shocks can be interpreted as the occasional 'plucking down' of an economy from its (upward-trended) 'maximum feasible growth ceiling' (given by an economy's resources and the efficiency with which they are utilized), and to which it subsequently recovers: this is essentially the approach discussed, for example, by Friedman, 1993, in his work on business fluctuations in the US macroeconomy. This obviously requires estimating what this 'maximum feasible growth ceiling' actually is: Friedman himself suggests the hypothetical line connecting successive cyclical peaks.

A common theme running through these various approaches is that recessions represent a form of economic 'shock' in the sense that they are (in general) unexpected and unpredictable events that disrupt the 'normal' growth path of an economy. Recessions are distinctly negative in nature, involving the contraction of economic activity (output), the possible closure of firms, and a fall in employment (due to a cessation of new hires and a rise in layoffs or redundancies). Given its association with the study of shocks, the notion of resilience is a potentially useful concept with which to examine how regions are affected by recessionary downturns (Martin, 2012). The basic idea of resilience is that it captures how an entity or system reacts to and recovers from an adverse disruption. Interest focuses on how long the entity or system in question takes to return to its pre-shock state, and whether in fact it returns to that state or is moved by the shock to some other (preferably more favourable) state. Although the idea of resilience, which originated in the physical sciences, has been used in ecology and certain branches of psychology for some time, it has yet to receive much attention in economics (though one or two authors have begun to explore its applicability - see Briguglio, 2004; Briguglio et al, 2009). However, in recent years it has been taken up with some enthusiasm in economic geography and regional studies, where there is now a growing literature (for example, Cambridge Journal of Regions, Economy and Society, 2010; Hassink, 2010; Bristow, 2010; Simmie and Martin, 2010; Martin, 2012; Fingleton, Garretsen, and Martin, 2012; Scott, 2013; Doran and Fingleton, 2013; Martin and Sunley, 2015; Boschma, 2015). In his discussion, Martin 
(2012) distinguished between four 'dimensions' or aspects of regional resilience to recessionary (or other such shocks): Resistance (degree of sensitivity or depth of reaction to the shock), Recovery (speed and degree of recovery from the shock), Re-orientation (extent of reorientation and adaptability of regional economy in response to the shock) and Renewal (extent to which regional economy renews its pre-shock growth path or hysteretic shift to a new path). In their comprehensive exploration of the meaning and application of the notion of resilience in the study of regional development, Martin and Sunley (2015) revise and develop this characterization in a number of ways. First, they emphasise that resilience is a multifaceted process, not a singular, static state of affairs or fixed characteristic of a regional or local economy, and can be viewed as comprising four sequential (and recursive) steps: the risk (or vulnerability) of a region's firms, industries, workers and institutions to shocks; the resistance of those firms, industries, workers and institutions to the impact of shocks; the ability or otherwise of the region's firms, industries, workers and institutions to undergo the adjustments and adaptations necessary to resume core functions and performances, what we might call (adaptive) reorientation; and finally the degree and nature of recoverability from the shock (see Figure 1).

\section{Figure 1: Regional Resilience to Recessions}

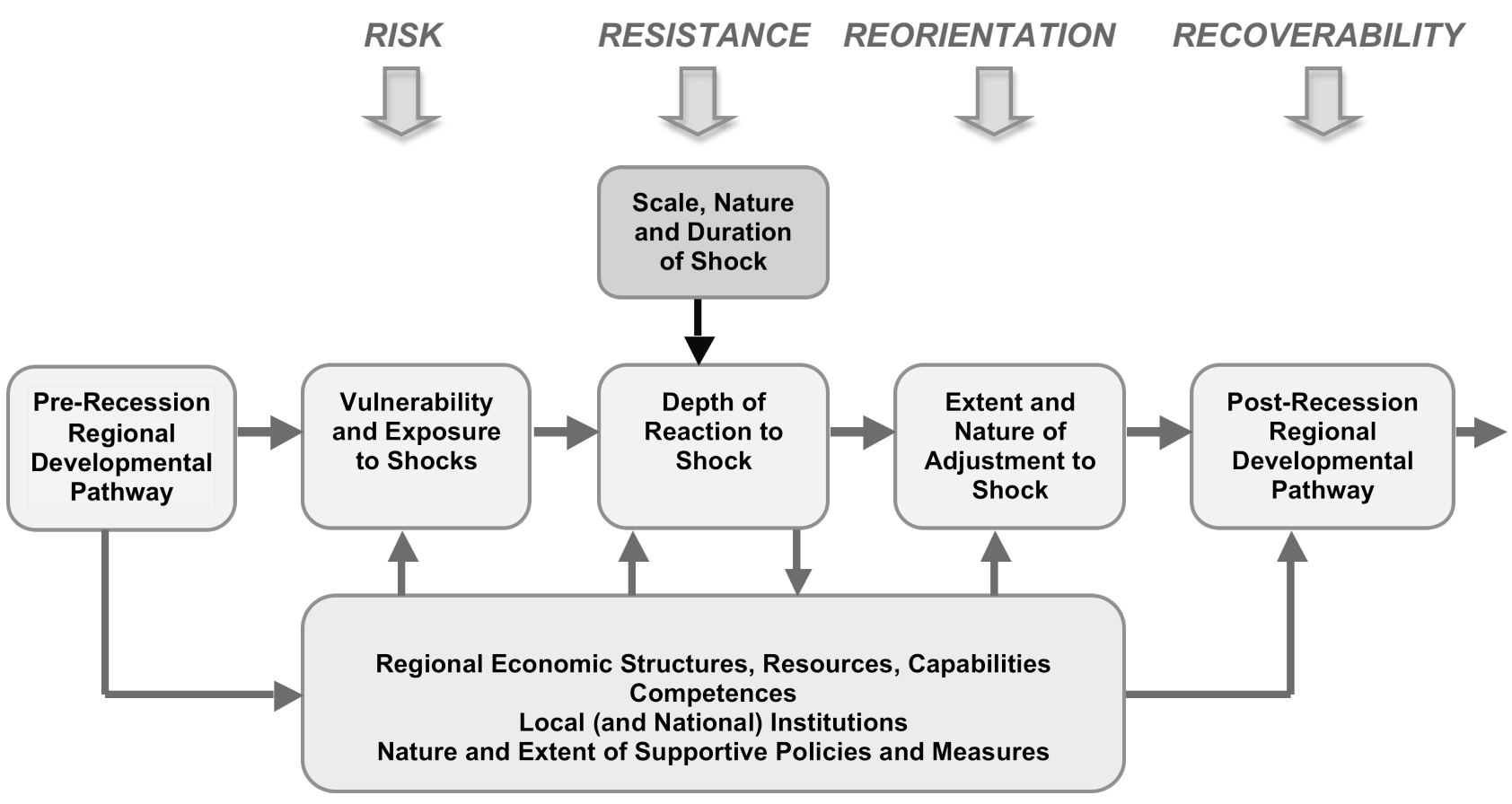

(Adapted from Martin and Sunley, 2015)

Second, these sequential aspects of the resilience process depend on the nature, depth and duration of the recession, on the prior growth path of a region, and on the various determinants of that growth path (regional economic structures, resources, capabilities 
and competences, together with any supportive measures undertaken by local or national institutions, including government, such as welfare policies, business support programmes and the like). Those determinants shape a region's risk and resistance (depth of reaction) to recessionary disturbances, but may themselves undergo shock-induced changes and adjustments, as the region's economic structures and forms undergo change and adaptations caused by, or in response to, the pressures of the shock. The ability of a region's economy - its firms, industries, technologies, working practices, institutional arrangements, etc - to undergo positive reconfiguration so as to restore core performances, such as profitability, full employment, investment and so on, defines that economy's adaptive robustness. The notion of 'adaptive robustness' is used in the study of complex biological, organizational and physical systems, where, traditionally, the term was interpreted as meaning that the characteristics of a system are unaffected by perturbations: that is, where there is a consistency (stability) of structure and function (see Whitacre, 2012). But more recently the term has been reconceptualised to refer to the ability of a system to resist external and internal disturbances and disruptions if necessary by undergoing plastic change in some aspects of its structure and components in order to maintain or restore certain core performances or functionalities (Kitano, 2004). It is important to recognize that under this new interpretation, robustness is concerned with maintaining some key functions or performances of a system rather than system states or structures, and that maintaining (or regaining) performance and functionality may actually involve - even require - changes in a system's structural components and mode of operation. Maintaining (or restoring) profitability, employment and growth can legitimately be viewed as 'core performances and functionalities' in an economic context, and clearly different configurations of industries, firms and skills can be commensurate with maintaining those core performances.

Thus, apart from the technical issues involved, from an ontological viewpoint treating recessions as shocks to an autonomous 'trend' or equilibrium economic path is not unproblematic. To do so is to assume that a trend or equilibrium exists independently of cyclical movements, whereas in reality the two may be inextricably interrelated. Slowmoving structural changes and shifts, for example, may alter the cyclical behaviour of an economy; and conversely, a major recessionary shock may well change the pace and direction of structural and developmental change. Separating trend and cycle may thus be misleading, however sophisticated the technique used to undertake the exercise. Our approach here is to not to assume some autonomous path or to attempt to 'detrend' our regional series, but to focus on how regions react to recessions defined by the national downswings from peak to trough, and recoveries defined as the national upswings from trough to peak. 


\section{Measuring Resistance to and Recoverability from Recessionary Shocks}

To do this, we focus specifically on measuring two of the four dimensions of resilience set out in Figure 1, namely resistance and recoverability, before turning to the role of structure and the issue of adaptability in the next section. Several different measures of resistance and recoverability can be devised. At their simplest, they could just be the straightforward proportionate falls and increases in the chosen indicator (such as regional employment or output). But a more convincing approach is to compare such movements (contractions and expansions) in relation to expected or 'counterfactual' falls and increases in the regions concerned. For example, in their study of the resilience of US counties to the recession of 2008-9, Hans and Goetz (2013) compute such expected falls and recoveries by projecting forward into the recession (2008-9) and recovery (2009-2011) what local county output would have been on the basis of its own recent 'average trend growth rate', estimated over 2005-8: in effect what would have happened in the absence of the recession. The deviation of the actual level of county output from its corresponding trend-based 'expected' level is then used to compute a measure of what they term 'drop' and 'rebound', and the ratio of the latter to the former is deployed to yield a measure of 'resilience'.4

Since we are interested in how different regions (or localities or cities) are affected by a common (nation-wide) recession, a particular type of expected or 'counterfactual' reaction suggests itself, namely the resistance and recovery of the national economy as a whole. In other words, the expectation is that, other things being equal, each region's employment would contract (in recessions) and expand (in recoveries) at the same rate as that nationally. Thus the expected change in, say, employment in region $r$ during a recession or recovery, say of duration $k$ periods, would be given as

$$
\left(\Delta E_{r}^{t+k}\right)^{e}=\sum_{i} g_{N}^{t+k} E_{i r}^{t}
$$

where $g_{N}^{t+k}$ is the rate of contraction (in recession) or expansion (in recovery) of national employment, and $E_{i r}^{t}$ is employment in industry $i$ in region $r$ in starting time t, the base year, that is the turning point into recession or into recovery. 5 Then a measure of regional resistance can be expressed as

\footnotetext{
4 The period 2005-2008 would seem to us to be a very short time span from which to calculate 'an average trend' for computing expected (counterfactual) levels of output during the 2008-2009 recession and recovery phase of 2009-2011.

5 Exactly the same measures could be made using output. We prefer employment as our measure of regional reactions to recessions for the reasons stated below.
} 


$$
\operatorname{Re} \operatorname{sis}_{r}=\frac{\left(\Delta E_{r}^{\text {Contraction }}\right)-\left(\Delta E_{r}^{\text {Contraction }}\right)^{\text {expected }}}{\left|\left(\Delta E_{r}^{\text {Contraction }}\right)^{\text {expected }}\right|}
$$

and a corresponding measure of regional recoverability as

$$
\operatorname{Recov} v_{r}=\frac{\left(\Delta E_{r}^{\text {Recovery }}\right)-\left(\Delta E_{r}^{\text {Recovery }}\right)^{\text {expected }}}{\left(\Delta E_{r}^{\text {Recovery }}\right)^{\text {expected }}}
$$

By definition, the two measures in Equations (2) and (3) are centred around zero. Thus a positive value of $\mathrm{Re}_{\text {sis }}$, indicates that a region is more resistant to recession (that is, less affected) than the national economy, and less resistant (more affected) for a negative value. For example, a value of Re sis $s_{r}$ of, say 0.5, would indicate that the regional economy in question is 50 percent more resistant than the national economy, and a value of -0.5 that its resistance is only half that of the nation. Similarly, a region that has a positive value of Recov $r$ has a higher recoverability compared to the national economy, and conversely if it has a negative value. This gives a $2 \times 2$ configuration of resilience possibilities (Figure 2). On a priori grounds we might expect most regions to fall in either the top right (strong resistance and strong recoverability) or bottom left (weak resistance and weak recoverability) quadrants, although regions that fall in either the top left, and particularly bottom right (weak resistance but strong recoverability) quadrants are also of interest.

\section{Figure 2: Combinations of Resistance and Recoverability}

\begin{tabular}{cc|l|l|}
\cline { 3 - 4 } Resistance & 0.0 & $\begin{array}{l}\text { MOST RESILIENT } \\
\text { Good resistance but } \\
\text { weak recoverability }\end{array}$ & $\begin{array}{l}\text { Good resistance and } \\
\text { good recoverability }\end{array}$ \\
\cline { 3 - 4 } & $<0.0$ & $\begin{array}{l}\text { Weak resistance and } \\
\text { weak recoverability } \\
\text { LEAST RESILIENT }\end{array}$ & $\begin{array}{l}\text { Weak resistance but } \\
\text { good recoverability }\end{array}$ \\
\hline & \multicolumn{2}{|c|}{0.0} \\
$<0.0 \quad$ Recoverability
\end{tabular}

In using these measures to investigate the impact of the last recessions on the major regions of the UK, we analyse regional employment rather than output, on the grounds 
that, ultimately, it is a region's workforce that bears the brunt of adjustment in recessionary contractions: workers laid off during a recession may or may not be rehired when the demand for a region's products and services begins to recover, and of those who remain unemployed, some may have to move to other regions to find a job, while those who cannot move may well end up as long-term unemployed, or even drop out of the labour force. 6 In general, cyclical movements in employment tend to be more pronounced than those in output, although in the most recent recession the proportionate fall in employment was untypically less than that in output.

As mentioned above, there have been four main recession-recovery cycles in the UK economy over the past forty years: namely, from peak to peak, 1974-79; 1979-90; 19902008; and from 2008 onwards, this last cycle being as yet incomplete. In terms of employment movements, there is a striking difference between the two downturns of 19741976 and 2008-2010 on the one hand, and those of 1979-83 and 1990-93 on the other (see Figure 3). The latter two recessions were far more severe and of far greater duration than the other two. The proportionate drop in employment in the downturns of 1979-83 and 1990-93 was around three times that in the recessions of 1974-76 and 2008-10, and employment took twice as long to recover to its pre-recession peak level.

Figure 3: UK Employment over the Last Four Recession-Recovery Cycles, 1971-2014

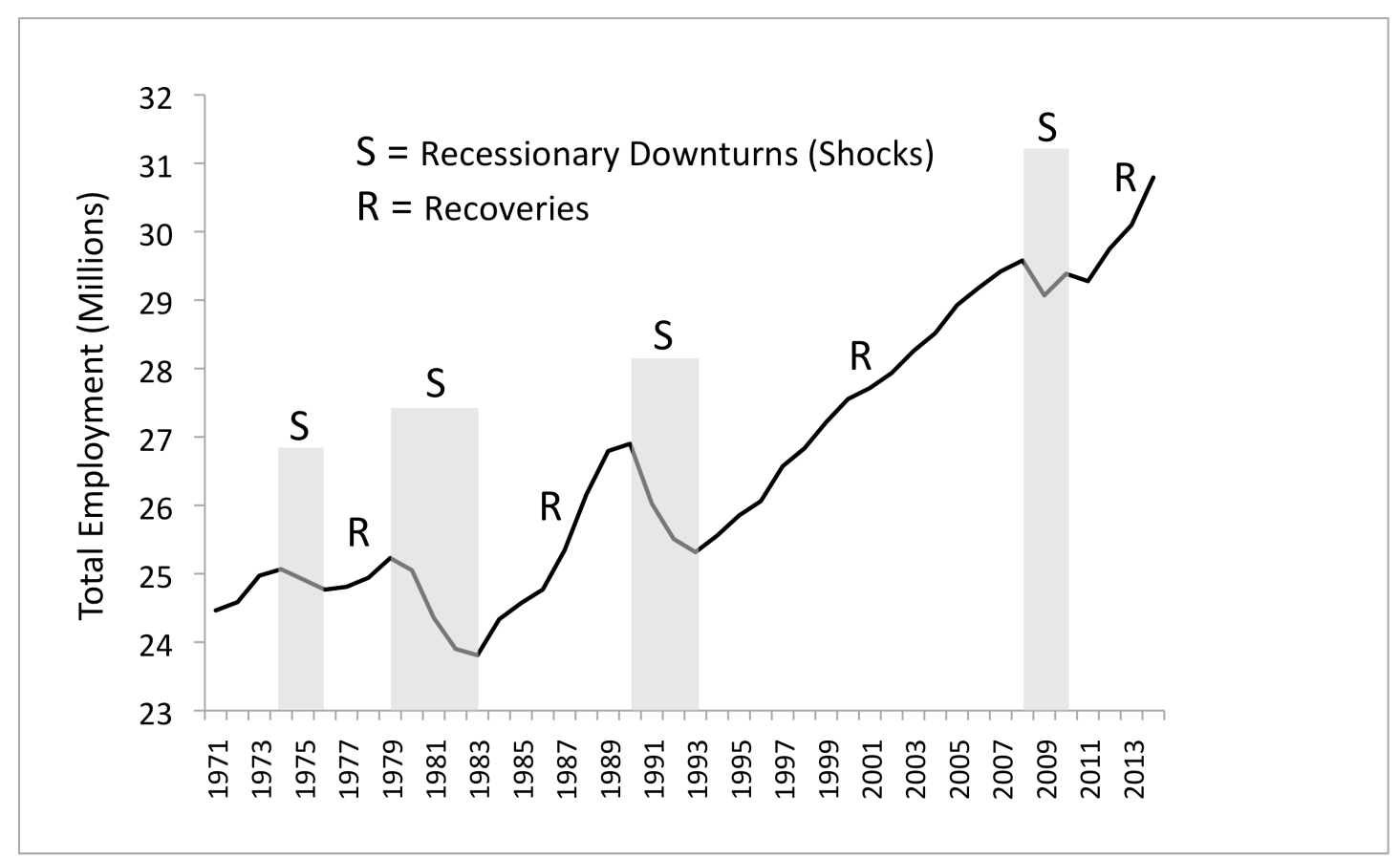

Source of data: Office for National Statistics Note: The most recent cycle is as yet incomplete

\footnotetext{
6 And some workers may only be able to retain their jobs, or find new ones in their region, if they are prepared to take wage cuts or reductions in working hours.
} 
Even a casual inspection of the employment paths of the major UK regions, shown by the annual series in Figure 4, suggests that both the intensity of employment contraction in these four recessions and the speed and extent of the subsequent recovery expansions have varied across regions. 7 Furthermore, it is apparent that these differential responses are

Figure 4: Employment in the UK Regions over the Last Four Recession-Recovery Cycles, 1971-2014

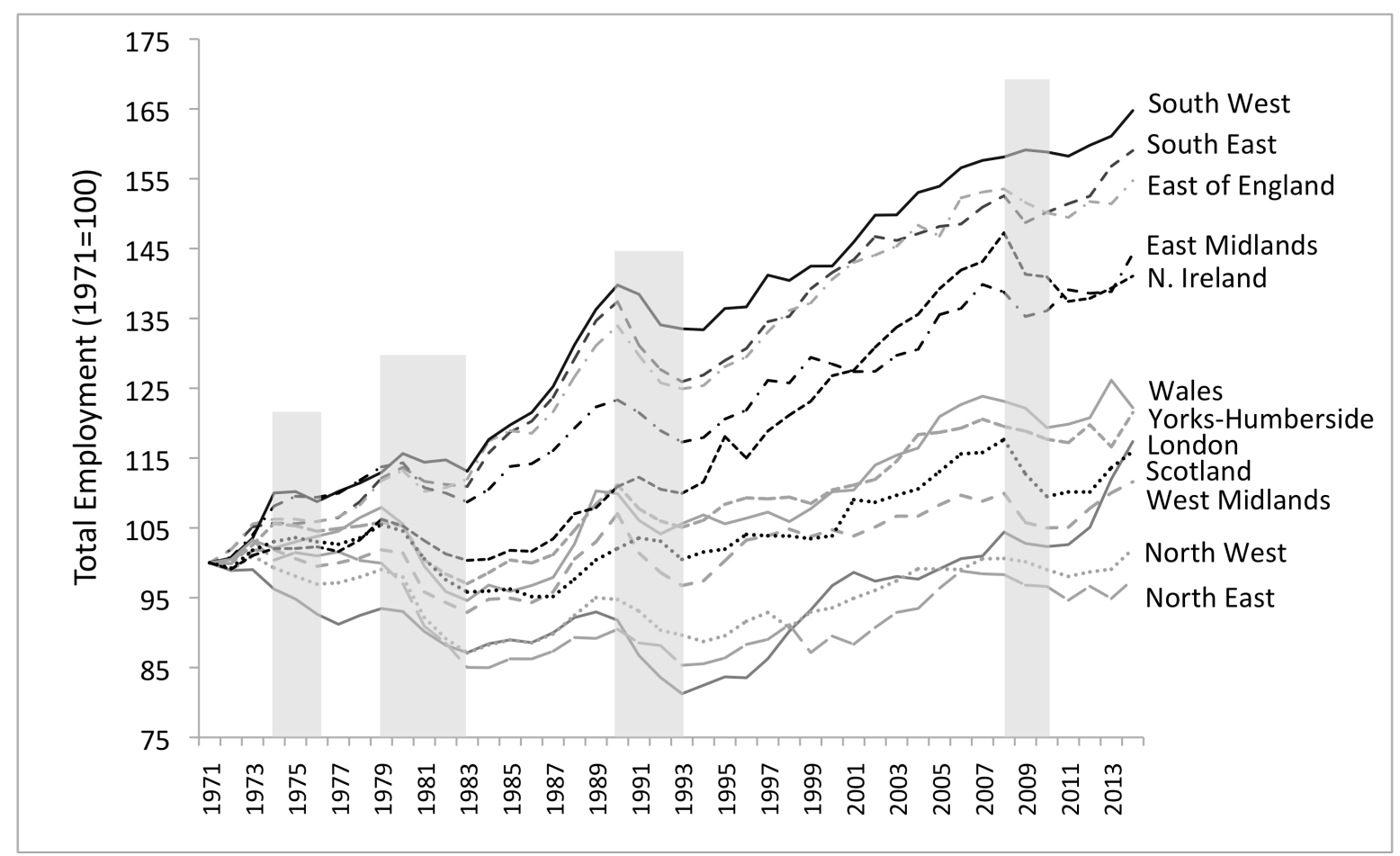

Source of data: Cambridge Econometrics Regional Economic Data Base Note: National recessionary downturns are shown shaded

inextricably bound up with quite divergent long-run employment trajectories among the regions. Thus it would appear regional employment paths diverged during both of the 1974-76 and 1979-83 recessions but noticeably less so in the subsequent downturns of 1990-93 and 2008-2010. At the same time, significant divergence took place in the

7 There is considerable 'noise' in quarterly employment data for regions, and, moreover, an industrial disaggregation of regional employment movements is not available at this observation frequency. For these reasons, in the rest of the paper we use annual data in the regional analyses. These data were kindly supplied by Cambridge Econometrics. Using annual data also minimizes differences in the timing of recession and recovery across the regions. Cycle turning points refer to the years in which peaks and troughs occurred at the national level. 
recoveries of 1976-1979 and 1983-1990 and has also occurred since 2010, but much less so in the long recovery-upswing phase of 1993-2008. The net result has been an overall marked cumulative divergence of employment growth paths amongst the regions, and especially between those in the south and those in the north of the country. There has long been discussion over the persistence, if not widening, of disparities in economic fortune between the south and east of the nation on the one hand, and the more northern areas on the other, often under the contentious and contested sobriquet of a 'North-South Divide' (see, for example, Martin 1988, 2004; Jackman and Savouri, 1999; Rowthorn, 2010; Gardiner, Martin, Sunley and Tyler, 2013). The employment evolutions in Figure 4 tend to support the idea of this broad divide. On the one hand, the South East, East of England, East Midlands and South West, have all expanded their employment by between 40-60 percent over the whole 1971-2014 period. Regions in the 'northern' group have experienced much slower employment growth, at best around 20-25 percent (in Wales and Yorkshire-Humberside), at worst barely any increase at all (in the North West and North East). Two regions complicate this 'North-South divide', however. Thus Northern Ireland has matched the four southern regions in terms of its rate of job growth, while up until the early-1990s recession, London, often regarded as a leading southern region, was in fact the worst performing region of all in terms of employment growth, and experienced - in common with the North East and North West regions - an overall decline in employment up to that juncture. Since then it has undergone a significant turnaround (see Gardiner, Martin, Sunley and Tyler, 2013; Martin, 2014), recording a growth rate on a par with that in regions in the southern group, though not sufficient to yet lift it into that group in terms of its long-run cumulative growth position.

The resistance and corresponding recoverability indices for the UK regions, calculated using Equations (2) and (3), for the last four recession-recovery cycles, are depicted in Figure 5, where each recession-recovery cycle is portrayed in the form of the fourquadrant typology shown in Figure 2.8 Several striking features are evident. The most obvious is that, apart from the cycle of recession-recovery cycle of 1990-2008, there has been a positive relationship between resistance and recoverability across regions: that is, regions that have been most resistant to recession have also enjoyed the strongest recoverability. However, this relationship is not particularly strong, with that between the recession of 1979-83 and the subsequent recovery of 1983-1990 being the most significant. The recession-recovery cycle of 1990-2008 emerges as quite different from the others. Secondly, and more notably, there are certain regions - specifically the South East, East of England and South West - that tend to recover strongly (in relation to the national economy) more or less regardless of their resistance to recession. At the same time, there other regions - the North East, Scotland and the North West - that tend to display weak

\footnotetext{
8 The recoverability indices for the most recent recovery, 2010-2014, are necessarily based on an incomplete cycle (which would be up to the next cyclical peak, whenever that occurs). The results for this recovery phase are therefore necessarily somewhat tentative.
} 
recoverability regardless of their resistance to recession. Thirdly, there are some regions that have undergone marked shifts in resilience from one recession-recovery cycle to the next, namely London, Northern Ireland and the West Midlands.

A fourth characteristic is that since the early-1970s, at least until the most recent recession and recovery, differences in resilience across UK regions appear to have narrowed (compare the horizontal and vertical scales of the graphs for successive cycles), which begs the question of whether this trend itself reflects a convergence in certain structural or other economic attributes of the regions over this period. The halt to this trend and the widening of regional differences in resilience over the most recent cycle, 2008-2014, is mainly due to the particular geography of recovery since 2010. This has been emphatically led by London, and the slower recovery in much of northern Britain could well be associated with the greater dependence of employment there on the public sector, which was the target of the Coalition Government's fiscal austerity programme. The continuation of this programme of cutting public expenditure under the Conservative Government elected in 2015 may well further slow the recoverability of this part of the UK.

\section{Figure 5: Regional Resistance and Recoverability for the Last Four Economic Cycles, UK}
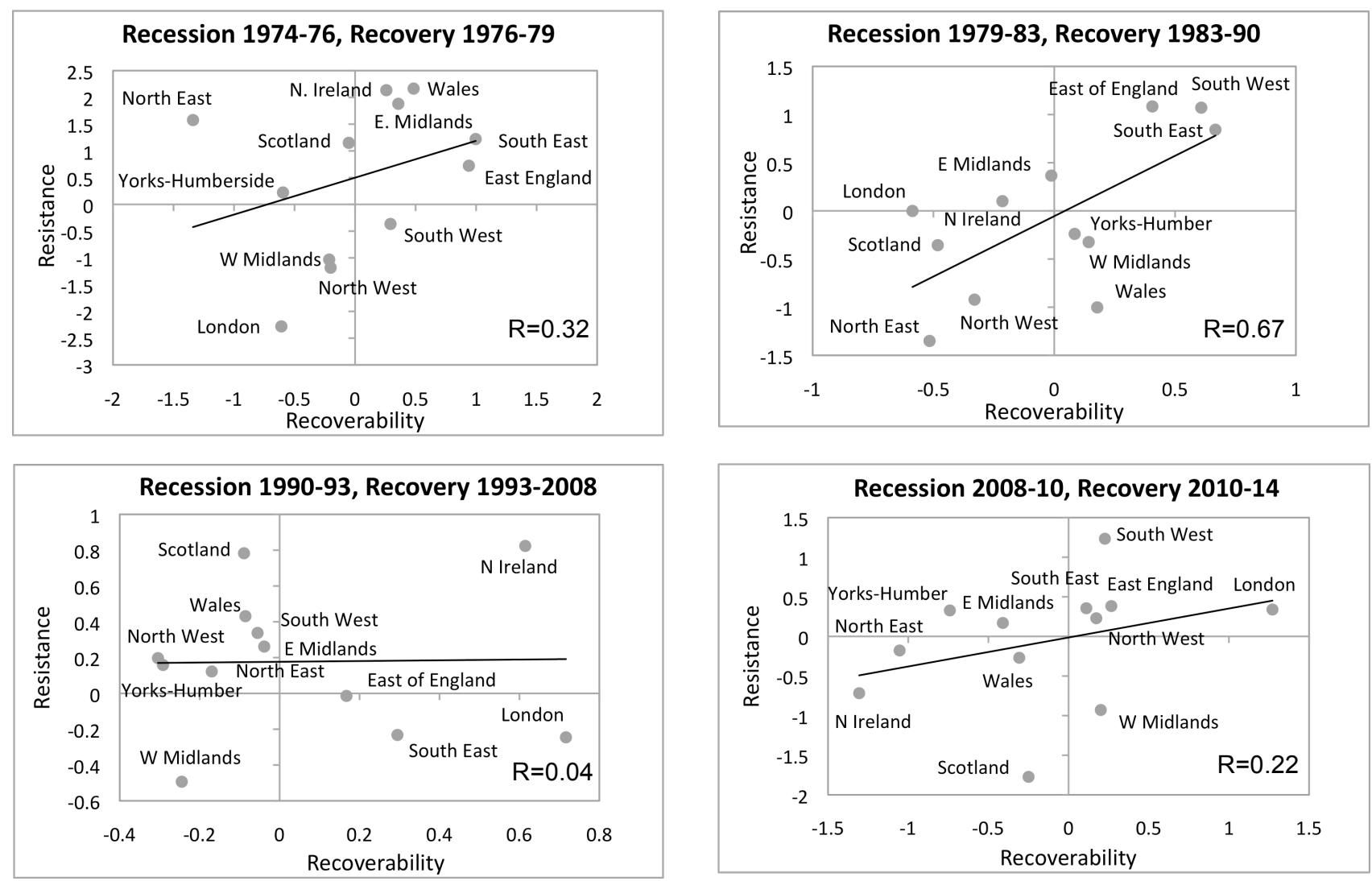

Notes: Calculated using equations (2) and (3). The cycle for 2008-2014 is as yet incomplete (see Footnote 7). 
What is clear from Figure 5, and from Tables 1 and 2, is that these findings caution against any idea that regional resilience is some fixed attribute or capacity, and hence against reading off any definite conclusions about regional resilience from an analysis of just one single recession or cycle, or from 'averaging' across cycles. 9 For one thing, recessions differ in their cause and nature, and for this reason alone are likely to impact differently across regions and localities. In the UK, the last four recessions have differed in their proximate causes: the oil crisis induced recession of 1974-76 impacted particularly on manufacturing, and the recession of 1979-82 even more so, that of 1990-93 also hit private services, while that of 2008-2010 was largely attributable to the sharp credit squeeze triggered by the financial crisis. Regional reactions to these different types of recession might be expected to have varied accordingly. But in addition, longer term processes and developments may also change regional resistance to and recovery from successive recessionary contractions. In this context, given that our study period spans 40 years, marked changes have inevitably occurred to the economies of the regions, including major shifts in industrial structures. The impact of the latter, in particular, warrants investigation, and this is the focus of the remainder of the paper.

Table 1: Correlations between Regional Resistance to Different Recessions

\begin{tabular}{lccc}
\hline & $\begin{array}{c}\text { Resistance } \\
1979-1983\end{array}$ & $\begin{array}{c}\text { Resistance } \\
1990-1993\end{array}$ & $\begin{array}{c}\text { Resistance } \\
\text { 2008-2010 }\end{array}$ \\
\hline Resistance 1974-1976 & $-0.049(0.879)$ & $0.677(0.016)$ & $-0.230(0.473)$ \\
Resistance 1979-1983 & & $-0.123(0.702)$ & $0.341(0.278)$ \\
Resistance 1990-1993 & & & $-0.299(0.346)$ \\
\hline
\end{tabular}

Note: p-values in parentheses

Table 2: Correlations between Regional Recoverability to Different Recessions

\begin{tabular}{lccc}
\hline & $\begin{array}{c}\text { Recoverability } \\
1983-1990\end{array}$ & $\begin{array}{c}\text { Recoverability } \\
1993-2008\end{array}$ & $\begin{array}{c}\text { Recoverability } \\
2010-2014\end{array}$ \\
\hline Recoverability 1976-1979 & $0.725(0.008)$ & $0.259(0.416)$ & $0.044(0.892)$ \\
Recoverability 1983-1990 & & $-0.120(0.710)$ & $-0.299(0.087)$ \\
Recoverability 1993-2008 & & & $-0.298(0.0972)$ \\
\hline
\end{tabular}

Note: p-values in parentheses

\footnotetext{
9 Thus impulse-response function analyses and similar time series procedures that typically use an entire time series to estimate the response profile of a regional economy to a unit shock may be misleading.
} 


\section{The Role of Industrial Structure in Shaping Regional Reactions to Economic Cycles}

The resilience of regional and local economies to recessions is determined by a complex array of factors (see Figure 6). As depicted in Figure 1, these factors shape the vulnerability of a region's economy to recessionary shocks, its resistance to such shocks, its adaptability, and its recoverability. In the process, those very same characteristics and factors may themselves undergo permanent change and transformation so that regional reactions to the next recessionary shock may alter accordingly (see Martin and Sunley, 2015). It is in this context that the notions of resilience as 'positive adaptation' or as a new developmental pathway (Figure 1) are relevant. Many of these factors - around labour markets, financial systems and governance arrangements - might be described as 'institutional' in so far as they represent more durable patterns and combinations of formal and informal ways of organizing economic activity. However, most recent studies have related these institutional dimensions to long-run development rather than to responses to adverse shocks (see Gertler, 2010; Rodriguez Pose, 2013).

\section{Figure 6: Determinants of Regional Economic Resilience}

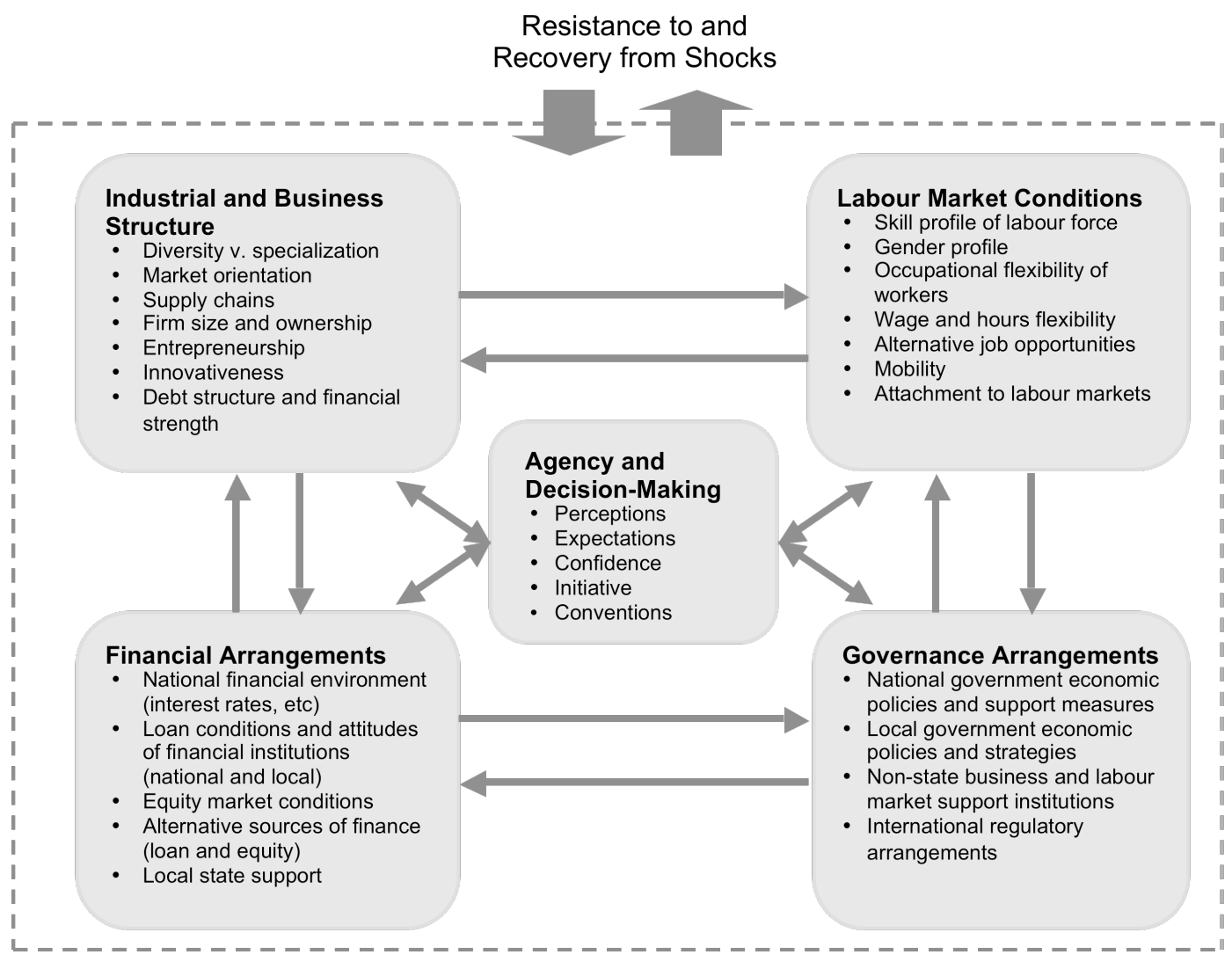


Isolating the contribution of the multifarious determinants shown in Figure 6 to resilience would be a major task, assuming that the requisite data were even available, and would be best accomplished by a case-study orientated research strategy. Our aim here is much more modest. Of the various factors assumed to exert a formative influence on the sensitivity of regional and local economies to cyclical shocks and perturbations, industrial structure has frequently been assigned key importance since it shapes a region's exports and hence exposure to externally-originating demand shocks. Indeed, in the past couple of years or so, the issue of regional economic structure has attracted renewed discussion and debate. In essence, the key question is whether specialisation is 'good or bad' for regional development. According to some economic geographers, industrial specialisation is the major driver of regional economic growth (Storper, 2013; Storper et al, 2015). Others, however, argue that it is the diversity - the complexity - of a region's or city's economic structure (its industries or its products) that imbues it with higher growth and greater stability (see for example, Hausmann et al, 2013). Still others argue that what matters for regional economic growth and stability over the long run is 'diversified specialisation' (Farhauer and Kröll, 2011), while yet others emphasise what they call 'related variety' (Frenken, Van Oort and Verburg, 2007). Also, other possible determinants - such as the age structure of local firms, wage costs, workforce skills, workplace cultures, entrepreneurship and business formation rates, and the like - are to some extent themselves functions of a region's industrial composition and its industrial history. Indeed, some of these industry-related factors may linger on, in a path dependent manner, even if the particular industries around which they developed and with which they were originally associated, have long since declined or disappeared.

In his interesting study, Conroy (1973) demonstrates in some detail how a region's economic structure - what he calls its 'industrial portfolio', the particular mix of economic activities and their interrelationships - can influence the reactions of a region's economy to recessionary disturbances and fluctuations. Subsequent studies have likewise assigned a similar importance to regional economic structure, and to the possible implications of structural diversity (or variety) versus specialisation for cyclical stability (for example, Sherwood-Call, 1990; Siegel et at, 1994, 1995; Dissart, 2003; Ormerod, 2008). A recurring theme is that, other things being equal, a diverse or varied economic structure confers greater regional resistance to shocks than does a more specialised structure, since different industries themselves have different elasticities of demand, different export markets, different dependence on monetary conditions (exchange rates, interest rates, debtfinancing), and so on (see, Garcia-Mila and McGuire, 1993; Belke and Heine, 2004). Put another way, a diverse economic structure should allow a regional economy to 'spread risk'. Conversely, a highly specialised regional economy - say one heavily dependent on manufacturing - is potentially more vulnerable and unstable, since if its principal industrial specialism is badly hit by a downturn it has much less scope for other, less- 
sensitive (more resistant), industries to provide some measure of buffering against the contraction. For these reasons, according to Davies and Tonts, 2010):

The general contention is that those places with diverse economies are more resilient in socio-economic terms than those with a narrow economic base (p. 232).

Table 3: Sectoral Employment Growth Rates and 'Cyclical Sensitivity', UK, 1971-2014

\begin{tabular}{|c|c|c|}
\hline Sector & $\begin{array}{c}\text { Average } \\
\text { Annual } \\
\text { Growth Rate, } \\
\text { 1971-2014 } \\
\text { Percent }\end{array}$ & $\begin{array}{c}\text { Coefficient of } \\
\text { 'Cyclical } \\
\text { Sensitivity' }\end{array}$ \\
\hline Agriculture & -1.21 & 0.88 \\
\hline Mining and quarrying & -3.80 & 1.19 \\
\hline Food, drink and tobacco & -1.38 & 0.76 \\
\hline Textiles, clothing and leather & -5.18 & 0.95 \\
\hline Wood and paper & -1.93 & 1.15 \\
\hline Printing \& publishing & -1.53 & 1.07 \\
\hline Fuels and Chemicals & -2.25 & 1.63 \\
\hline Non-metal and mineral products & -2.08 & 1.87 \\
\hline Basic metals and metal products. & -2.73 & 1.63 \\
\hline Mechanical engineering & -2.30 & 1.72 \\
\hline Electronics, electrical and instrument engineering & -2.50 & 1.39 \\
\hline Motor vehicles & -3.00 & 2.18 \\
\hline Other transport equipment & -1.66 & 0.76 \\
\hline Other manufacturing & -1.44 & 1.11 \\
\hline Electricity, gas and water & -0.77 & 0.10 \\
\hline Construction & 0.36 & 2.08 \\
\hline Distribution & 0.03 & 0.90 \\
\hline Retailing & 0.77 & 0.72 \\
\hline Hotels and catering & 1.91 & 1.24 \\
\hline Transport and communications & -0.62 & 2.29 \\
\hline Finance and Insurance & 1.25 & 0.66 \\
\hline Other business services & 2.91 & 1.22 \\
\hline Public administration & -0.43 & 0.07 \\
\hline Education and health & 2.01 & 0.34 \\
\hline Other services & 3.06 & 0.74 \\
\hline Correlation & $\mathrm{R}=-0.42$ & \\
\hline
\end{tabular}

Note: The 'coefficient of cyclical sensitivity' is the regression coefficient of the percentage change in employment in an industry $\left(\% \Delta E_{i}\right)$ on the percentage change in national total employment $\left(\% \Delta E_{N}\right)$, calculated for the whole period, 1971-2014.

As Table 3 shows, not only have different UK sectors of activity had different rates of employment growth or decline over the 1971-2014 period as a whole, they have also 
differed in their 'cyclical sensitivity'.10 For example, manufacturing and production activities tend to have high cyclicality, motor vehicles and construction being prime examples, while employment growth in services and utilities tends to much more stable over time, as evidenced particularly by electricity, gas and water, retailing, health, education, and other services. There is evidence of an inverse relationship between 'cyclical sensitivity' and growth: those sectors with the highest long-term average growth rates tend to be the least cyclically sensitive, indicating that buoyant growth tends to be associated with greater resistance to shocks. These attributes give some credence to the argument that within a regional setting, a diverse industrial structure might be expected to be less vulnerable and resilient to recessions. However, specialisation need not be problematic per se: much depends on the particular cyclical vulnerability or sensitivity of that specialisation. A region that is specialised in manufacturing, for instance, is likely to be much more affected by recessions, other things being equal, than is a region that has a disproportionate dependence on public services - or at least this was the case until the new era of fiscal austerity, when public sector activities have become much more vulnerable to shocks, both in and out of recession.

Empirically disentangling the influence of differences in industrial structure on regional responses to recessions is not straightforward. In their study of regional cyclical synchronicities across Europe, Partridge and Rickman (2005) first extract the trend from each region's employment series to generate a regional 'cyclical series', to which they then apply what is essentially a shift-share decomposition to identify the contribution of industrial structure to each region's cyclicity. For the reasons we enumerated above, however, distinguishing trend from cycles may not be ontologically meaningful, so we do not adopt that approach here. Further, since, as we saw in the previous section, a region's reaction to and recover from recessionary shocks may well vary from one cycle to another, and since this may be due to changes in regional industrial structures over time - perhaps as a result of successive recessionary shocks themselves - we wish to identify the impact of industrial structure on regional resistance separately for each downturn and each subsequent recovery upswing.

More specifically, and in order to link the analysis with the resistance and recovery indices computed in Section 2, we apply a shift-share procedure to decompose the change in a region's employment during a recession or recovery period, $\Delta E_{r}^{\text {recess }}$ or $\Delta E_{r}^{\text {recov }}$ into three components: a national component, an industrial mix effect and a regional 'shift' or regional 'competitiveness' effect. For a given change over the time interval $t, t+k$ and for a given industry $i$ in region $r$, the shift-share decomposition can be written as

\footnotetext{
10 These 25 sectors are those used in the regional analysis that follows. This is the finest degree of consistent regional industrial disaggregation possible across the entire historical period studied here.
} 


$$
\Delta E_{r}^{t+k}=\Sigma_{i}\left(g_{N}^{t+k} E_{i r}^{t}\right)+\Sigma_{i}\left(g_{i N}^{t+k}-g_{N}^{t+k}\right) E_{i r}^{t}+\Sigma_{i}\left(g_{i r}^{t+k}-g_{i N}^{t+k}\right) E_{i r}^{t}
$$

(a)

(c)

where $g_{N}^{t+k}$, is the percentage rate of change of national employment over the period of recession or recovery, $g_{i N}^{t+k}$ is the corresponding rate of change of employment in sector $i$ nationally, and $g_{i r}^{t+k}$ the rate of change of employment in that sector in region, $r$; and where

(a) is the national effect or component, which is the change in regional employment in a downturn (or recovery) that would be expected if employment in each of the region's industries contracted (or increased) at the same rate as the national rate of employment change. In other words, this is identical to the 'expected' (counterfactual) regional response $\left(\Delta E_{i}^{t+k}\right)^{e}$ that was used in equations (2) and (3);

(b) is the industrial mix effect, which is the fall (or increase) in regional employment in a recession (or recovery) allowing for the fact that some national industries may contract in recession or expand in recovery at faster rates than national employment as a whole. It thus captures that part of a region's relative resistance to and recoverability from recession attributable to the region's mix of (specialisation in) more and less nationally resilient industries. The more a region's economic structure is dominated by sectors that nationally are more (or less) resilient to recessions, the more (or less) resilient will the region be to recession compared to the national economy;

(c) is the difference between actual regional employment change in recession or recovery and that part of regional employment change attributable to national and industrial mix effects, and captures differences in behaviour between the industries in a region and those same industries nationally. In standard shift share analysis it is usually assumed to reflect features and characteristics specific to a region (socalled 'competitiveness effects') that result in its industries behaving differently from their national counterparts.

By taking the national component (a) to the left-hand side of (4), that is,

$$
\Delta E_{r}^{t+k}-\Sigma_{i}\left(g_{N}^{t+k} E_{i r}^{t}\right)=\Sigma_{i}\left(g_{i N}^{t+k}-g_{N}^{t+k}\right) E_{i r}^{t}+\Sigma_{i}\left(g_{i r}^{t+k}-g_{i N}^{t+k}\right) E_{i r}^{t}
$$

we are in effect decomposing the numerator in the resistance and recovery measures in Equations (2) and (3) into an industrial structure effect and a regional 'competitiveness' effect. Whereas standard shift share decomposes the change in regional employment over a specified period using the initial industrial structure and holding that constant over the 
period as a whole, here we use a dynamic version in which the changes are calculated on a year-by-year basis and cumulated over the recession or recovery concerned (see Barf and Knight, 1988, for a discussion of dynamic shift share; for a recent city application, see Martin, Gradiner and Tyler, 2014).11 This allows for the fact that regional (and national)

\section{Figure 7: The Contribution of 'Industry Mix' and 'Region-Specific' Effects to Regional Differential Resistance and Recoverability, Last Four Recession- Recovery Cycles}
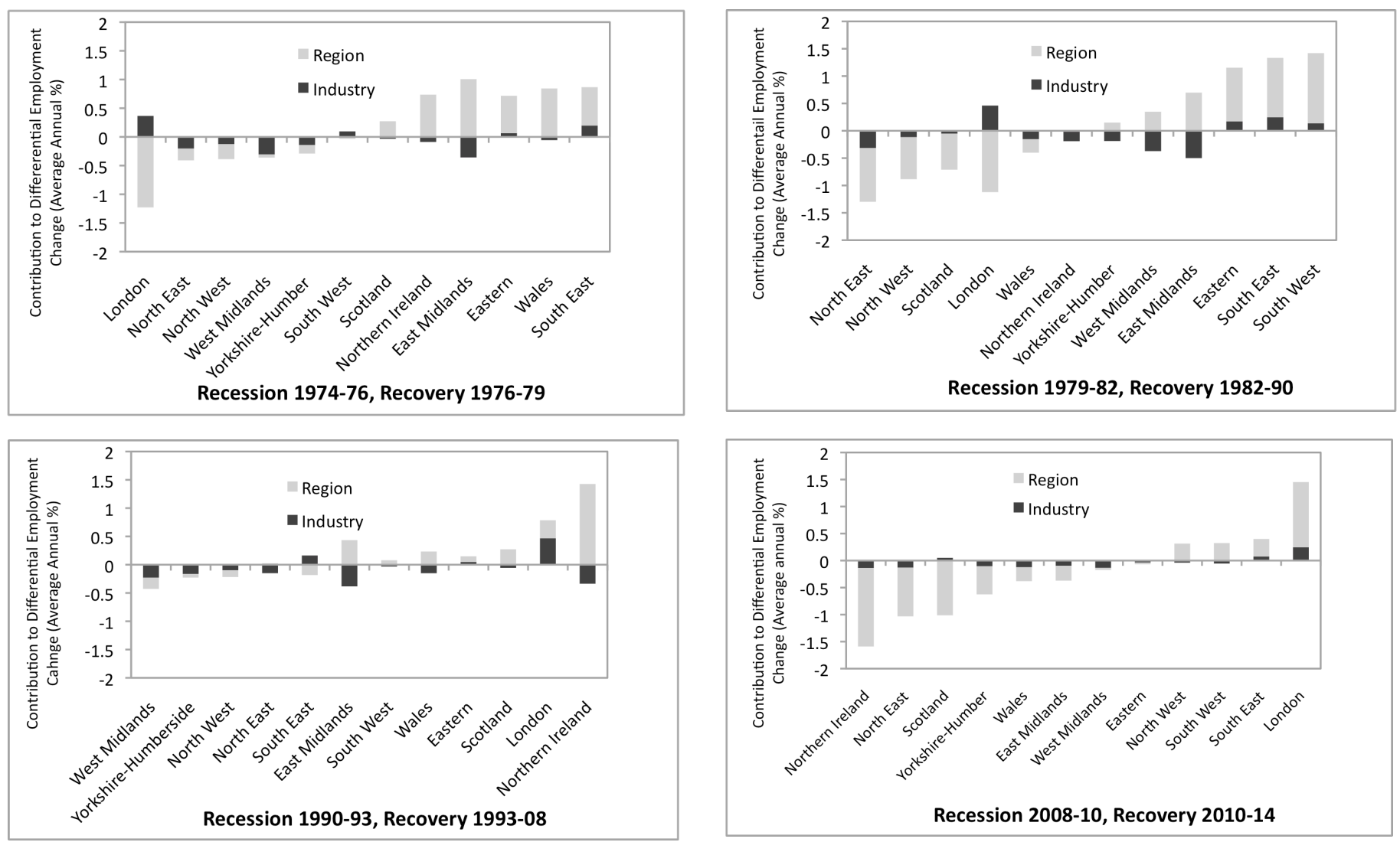

Note: Regions arranged (from left to right) in ascending size of total average annual percentage differential rate of employment change (above or below national rate) over each cycle

industry structures may change over time. Even during the course of a downturn, and especially if the contraction is a deep or prolonged one, shifts in a region's industrial structure may occur. During recoveries, which tend to be longer in duration than recessions, such shifts are even more likely. This dynamic version of shift share thus

11 Despite the fact that shift-share is a widely used decomposition technique, there are actually different variants, which can produce different results. For a recent review and assessment see Artige and van Neuss (2013), who also advance their own variant, which assumes a uniform distribution of sectors, by employment shares, in the calculation of the regional 'competitiveness' component. We also used their version of the procedure, and the results confirm the general pattern of those obtained using Equation 5, in particular the relative importance of the regional 'competitiveness' component compared to that of the industrial mix effect. 
allows for structural change, including any adaptation of a region's economic structure as part of its recovery from recession.

The results, using our 25-sector disaggregation, are shown in Figure 7. The graphs give the percentage change in regional employment attributable to industrial structure and regional shift factors in each region's percentage cumulative differential employment change (that is relative to the national or 'expected' change component), expressed as an annual average rate, over each of the four recession-recovery cycles. The regions in each graph are ranked from left to right by the size and sign of their total differential proportionate response, relative to the national response. The graphs give an indication of the contribution of structure and competitiveness effects to the position of each region in the quadrants in Figure 5. Thus, for example, for the 1974-79 recession-recovery cycle in the case of London, a positive industrial mix effect was far outweighed by a large negative regional effect, resulting overall in a negative resistance and recovery indices for the region as in the bottom left-hand quadrant of Figure 5; whilst at the other end of the distribution, Wales's relatively high resistance and recoverability indices over that same cycle were overwhelmingly the result of a strong positive regional effect.

Several features are evident from Figure 7. First, it is clear that, within the constraints of the level of sectoral disaggregation possible for this analysis, the relative role of industrial structure and region-specific effects has varied from one recession-recovery cycle to the next. This is not surprising, since it may reflect the different nature of each of the recessions, as discussed above. Second, it is also evident that, for the most part, the effect of industrial structure has been what one would expect: namely, that the effect has been negative in those regions - the North East, North West, Yorkshire Humberside, the West Midlands and East Midlands - that have been relatively more dependent on manufacturing, and positive in the more southern, less industrial, more service-orientated regions - the South East, London, the South West and Eastern region. London has consistently benefited from a favourable industrial mix effect. But thirdly, what is particularly striking is the relative contribution of region-specific effects to the differential responses of regions to recessions and recoveries. In almost all cases the regional effect exceeds the industry mix effect. In some instances, the regional 'competitiveness' effect has also changed significantly over time. For example, for the first two cycles London had a negative regional 'competitiveness' component in recessions and recovery: this now seems to have become positive, and substantial. On the other hand, in the East Midlands, positive regional competitiveness effect has declined over time, and now appears to be negative. Overall, the findings in Figure 7 suggest that, despite the importance often assigned in the literature to industrial structure in shaping regional growth and cyclical dynamics, in the case of the UK region-specific or 'competitiveness' effects seem to have played the dominant role in shaping how regions have reacted to economic cycles. 
Of course, it may be that the relative effect attributed to the 'regional' effect is influenced by the level of sectoral disaggregation used to determine the industrial mix component. A finer level of disaggregation might reveal a larger role for industrial mix and a smaller role for region-specific effects. But the size of the region-specific effect suggests that it is unlikely simply to be an artefact of the level of disaggregation used here. Further, our findings parallel similar results by Ogus and Skinner (2010) and Jones (2012) who used shift-share analysis to examine regional growth patterns (of output and employment, respectively) across the UK during the recovery ('long boom') of 1993-2008. They too found that for most of the UK regions, industrial structure played a secondary role.

\section{Cyclical Responses and Long-Run Structural Change}

The fact that regional differences in both resistance to and recoverability from recession have tended to diminish over time, at least until the most recent downturn (Figure 5), and that the relative contribution of industrial structure and 'competitiveness' to those responses has varied from one economic downturn to the next, and further that 'competitiveness' effects have tended to outweigh structural effects, suggests there are long-run trends and developments at work which have influenced how the UK regions have been impacted by successive economic cycles. One obvious possibility is that over time a region's industrial structure may undergo far-reaching changes, so that the region's cyclical behaviour will likewise change. In his classic study of regional business cycles in the US more than fifty years ago, Borts (1960) suggested that state differences in cyclical sensitivity were declining as a result of the diversification of state-level industrial structures, and similar results using more recent data have been obtained by Kim (1995). In the UK context, writing about the regional sensitivity to recessions as measured by unemployment movements in the 1980s and 1990s, Jackman and Savouri (1999) argued that shifts and changes in industrial structure across the UK regions had rendered this factor much less important as a source of regional differences in cyclical dynamics, particularly as between northern and southern areas of the country:

The traditional 'north-south divide' unemployment problem has all but disappeared in the 1990s. This may prove to be a permanent development, since the manufacturing and production sectors, the main sources of regional imbalance in the past, no longer dominate shifts in the employment structure to the same extent. Future shocks will have a more balanced regional incidence than has been the case in the past (p. 27).

Essentially, the underlying thrust of their argument was twofold. The first point was that over the course of the 1980 s and 1990s the process of deindustrialization had significantly reduced the historic reliance of the country's northern industrial regions on manufacturing, while their dependence on services (both private and public) had been correspondingly enhanced. That is to say, the economies of the old industrial regions - the 
West Midlands, North East, North West, Yorkshire-Humberside, Scotland and Wales, but we might also add London, since that had also been a major centre of manufacturing - had become more like those of the South East, East of England and South West. The second aspect to the argument was that since services (and especially public services) are much less prone to cyclical shocks (see Table 3), recessions would not only be less severe nationally, but also felt more evenly across the country.

To explore this issue, we follow Robson (2011) in calculating 'Lilien indexes' (Lilien, 1982) of structural change in the regions over the 1971-2012 period. This index is defined as

$$
\text { Lilien }_{r}^{t}=\left[\Sigma_{i}\left(E_{i r}^{t} / E_{r}^{t}\right)\left(\Delta \log E_{i r}^{t}-\Delta \log E_{r}^{t}\right)^{2}\right]^{1 / 2}
$$

that is, as the square root of the sum of sectoral-share-weighted deviations of regional sectoral employment changes from regional total employment change. This index gives a measure of the shifts of employment between sectors over a given time interval. Table 4 shows the results calculated over each recessionary and subsequent recovery periods (including the current but incomplete recovery phase). Although the degree of structural change has varied across regions, in all cases it has tended to be greatest during recoveries than in recessions, which is not surprising given that the former tend to be longer than the

\section{Table 4: Lilien Indices of Regional Structural Change in Successive Recession and Recovery Phases}

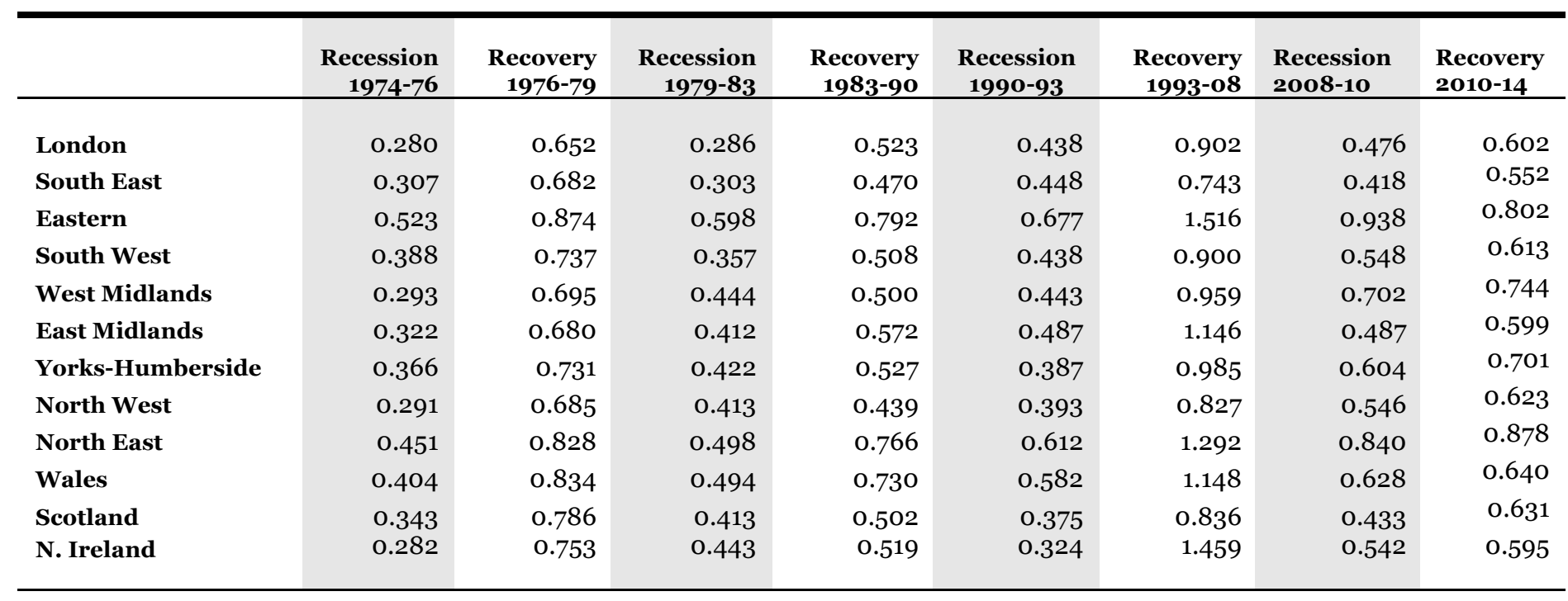

latter. Structural change was particularly marked during the long recovery phase from 1993-2008. In this period, structural change was most rapid in the Eastern region, the East Midlands, the North East, Wales, and Northern Ireland, and slowest in the South East, North West and Scotland. 
While these indices suggest that structural change has indeed been an ongoing feature of the regions, it tells us little about the nature or direction of that change. Some additional insight can be gained by calculating Krugman structural specialisation (dissimilarity) indices for each region, which compare the employment shares of each industry in a region with the corresponding shares nationally,

$$
D_{r}^{t}=\Sigma_{i}\left|\left(E_{i r}^{t} / E_{r}^{t}\right)-\left(E_{i N}^{t} / E_{N}^{t}\right)\right|
$$

The index ranges from o (no dissimilarity) to 2 (maximum dissimilarity): see Krugman (1993), Duranton and Puga (1999) and Barrios et al (2003) for discussions of this index. The higher the index, the more dissimilar - or more 'specialised' - is a region's economic structure relative to that of the national economy as a whole, and conversely. The indices for the UK regions over the period 1971-2014 are shown in Figure 8. Several features are apparent. The most obvious is that, with the exception of London, regional differences in industrial structure have declined over time (supporting Jackman and Savouri's argument), although the actual pattern of regional differences in specialisation has remained relatively stable, with the old industrial regions of Northern Ireland, Wales, the North East, and West Midlands, together with London, remaining more relatively specialised than regions such as the North West, South East, Eastern and South West. For most regions the decline in structural dissimilarity occurred mainly in the first two decades of the period, in the 1970s and 1980s, and since the early-1990s recession, differences in industrial structure across the regions appear to have stabilized. The exception is Northern Ireland, where the decline in its structural dissimilarity accelerated after the early-1990s. The basic point, however, is that, apart from London, over the past forty years or so, the regions have become increasingly similar in terms of their economic composition.

But while the Krugman index indicates that regional industrial structures have converged, this may be - as Jackman and Savouri contend - because each region has become increasingly orientated around, that is specialised in, services: that is, regional sectoral structures can converge because each region is becoming similarly specialised. Tables 5 and 6 show the shares of manufacturing and private services in regional employment over the entire study period. The decline in manufacturing as a share of total regional employment has been dramatic, particularly in the recession of 1979-83, and in the long recovery boom years of 1997-2008 (Table 5). Those regions that were most dependent $n$ manufacturing back in the early-1970s - West Midlands, East Midlands, YorkshireHumberside, North West and North East - still had the highest proportions of employment in that sector in 2010, but the degree of dependence had slumped by then. At the same time, the increasing concentration of regional employment structures around private services is equally striking (Table 6); by the end of our study period, all of the regions had become firmly orientated around private services. 
Figure 8. Structural Specialisation Among UK Regions, 1971-2014

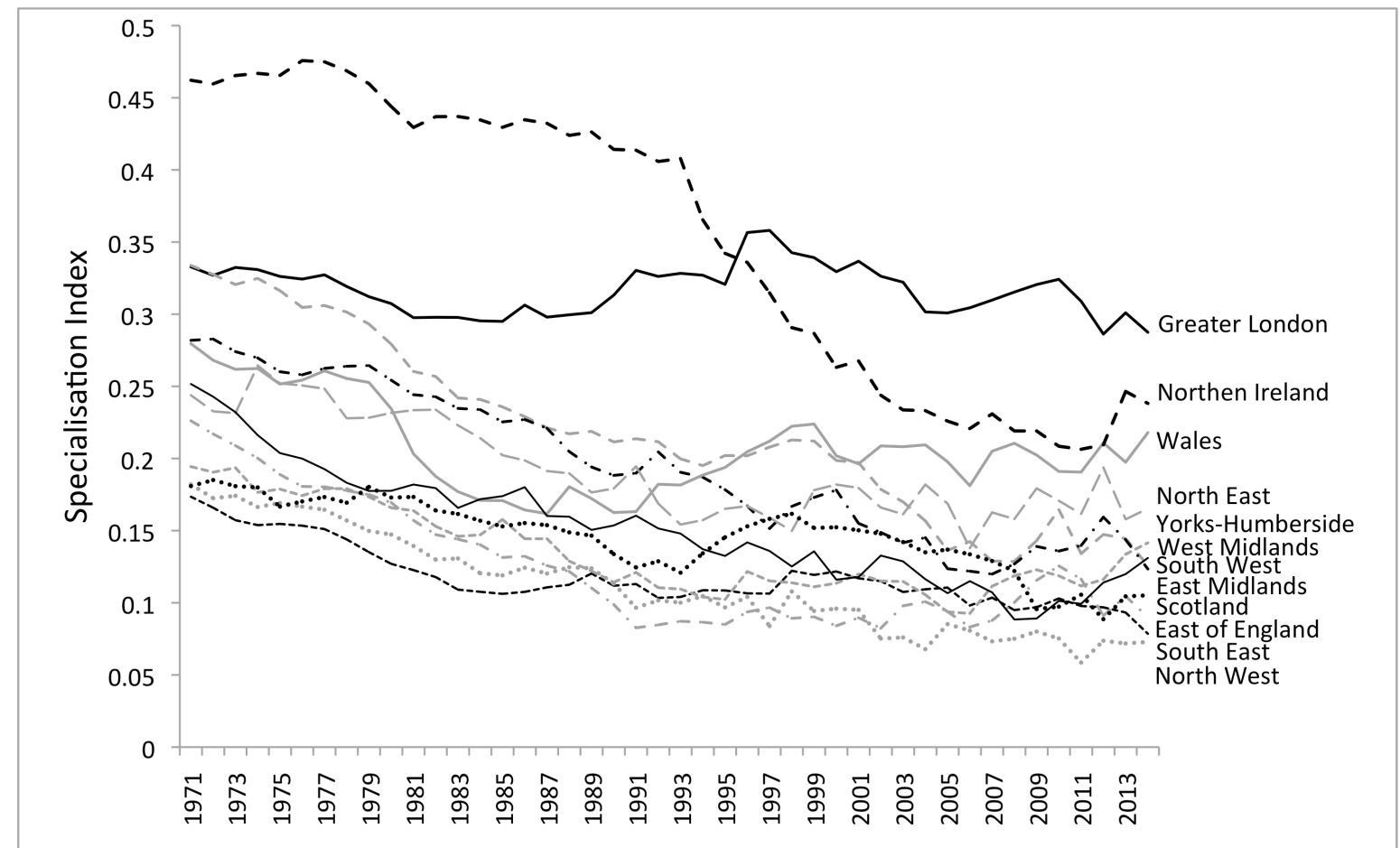

Table 5: The Declining Share of Manufacturing in Regional Employment, by Cyclical Phases (Percent)

\begin{tabular}{|c|c|c|c|c|c|c|c|}
\hline & $\begin{array}{r}1976 \\
\text { Trough }\end{array}$ & $\begin{array}{l}1979 \\
\text { Peak }\end{array}$ & $\begin{array}{r}1983 \\
\text { Trough }\end{array}$ & $\begin{array}{l}1990 \\
\text { Peak }\end{array}$ & $\begin{array}{c}1993 \\
\text { Trough }\end{array}$ & $\begin{array}{l}2008 \\
\text { Peak }\end{array}$ & $\begin{array}{r}2010 \\
\text { Trough }\end{array}$ \\
\hline London & 17.5 & 15.1 & 12.7 & 8.5 & 6.8 & $3 \cdot 3$ & 2.7 \\
\hline South East & 22.7 & 22.1 & 18.9 & 14.8 & 12.5 & 7.2 & 6.6 \\
\hline Eastern & 24.5 & 22.7 & 19.1 & 15.0 & 13.2 & 9.1 & 8.2 \\
\hline South West & 22.9 & 20.8 & $17 \cdot 5$ & 14.9 & 13.4 & 9.6 & 8.8 \\
\hline West Midlands & 38.6 & 34.9 & 28.5 & 24.4 & 21.5 & 12.4 & 11.6 \\
\hline East Midlands & $34 \cdot 3$ & 32.0 & 26.7 & $23 \cdot 5$ & 21.6 & 13.1 & 12.7 \\
\hline Yorkshire-Humberside & 31.2 & 28.3 & 22.3 & 19.3 & 18.2 & 11.4 & 10.4 \\
\hline North West & 31.5 & 27.9 & 22.7 & 19.6 & 17.5 & 10.5 & 9.4 \\
\hline North East & 33.0 & 29.2 & 24.0 & 20.8 & 18.4 & 11.0 & 10.0 \\
\hline Wales & 26.6 & 23.6 & 18.7 & 18.3 & 17.9 & 11.9 & 9.8 \\
\hline $\begin{array}{l}\text { Scotland } \\
\text { N. Ireland }\end{array}$ & $\begin{array}{l}26.5 \\
26.9\end{array}$ & $\begin{array}{l}22.7 \\
22.1\end{array}$ & $\begin{array}{l}18.5 \\
16.4\end{array}$ & $\begin{array}{l}15 \cdot 7 \\
14.8\end{array}$ & $\begin{array}{r}13.9 \\
15.1\end{array}$ & $\begin{array}{r}7.7 \\
10.2\end{array}$ & $\begin{array}{l}7.2 \\
9.4\end{array}$ \\
\hline
\end{tabular}


Table 6: The Increasing Share of Private Services in Regional Employment, by Cyclical Phases (Percent)

\begin{tabular}{|c|c|c|c|c|c|c|c|}
\hline & $\begin{array}{r}1976 \\
\text { Trough }\end{array}$ & $\begin{array}{l}1979 \\
\text { Peak }\end{array}$ & $\begin{array}{r}1983 \\
\text { Trough }\end{array}$ & $\begin{array}{l}1990 \\
\text { Peak }\end{array}$ & $\begin{array}{r}1993 \\
\text { Trough }\end{array}$ & $\begin{array}{r}2008 \\
\text { Peak }\end{array}$ & $\begin{array}{r}2010 \\
\text { Trough }\end{array}$ \\
\hline London & 57.7 & 59.4 & 62.2 & 66.7 & 69.3 & 74.0 & 73.7 \\
\hline South East & 44.8 & 47.7 & 50.6 & 55.6 & 57.9 & 63.8 & 62.2 \\
\hline Eastern & 43.6 & $45 \cdot 9$ & 50.2 & 55.1 & 57.6 & 62.1 & 62.3 \\
\hline South West & 76.5 & 75.9 & 74.8 & 76.8 & 74.8 & 76.6 & $75 \cdot 4$ \\
\hline West Midlands & 37.0 & 38.9 & 43.7 & 48.2 & 50.1 & 58.0 & 56.4 \\
\hline East Midlands & 38.0 & 40.1 & 44.2 & 47.7 & 51.2 & 57.1 & 57.2 \\
\hline Yorkshire-Humberside & 39.3 & 42.4 & 47.0 & 50.6 & 51.7 & $57 \cdot 3$ & 56.6 \\
\hline North West & 41.5 & 44.1 & 48.4 & 52.4 & $54 \cdot 9$ & 59.5 & 59.2 \\
\hline North East & 37.4 & 40.5 & 43.7 & 46.7 & 49.1 & 55.8 & 53.7 \\
\hline Wales & 39.7 & 41.7 & 46.0 & 48.5 & 49.2 & $53 \cdot 3$ & 53.9 \\
\hline Scotland & 41.0 & 43.6 & 46.8 & 51.1 & 53.8 & 58.0 & 58.6 \\
\hline N. Ireland & 29.6 & 32.1 & 34.5 & 37.8 & 38.0 & 51.1 & 52.8 \\
\hline
\end{tabular}

These findings go some way in explaining why industry mix seems to have played a relatively minor role in shaping the differences across UK regions in their responses to the past four economic cycles, and reinforces the view that it is the differential performance the 'competitiveness' - of a given industry from region to region that matters. Put another way, a given sector, say mechanical engineering or business services, performs differently, in terms of its reaction to a particular recession or recovery, from one region to another. Interestingly, in their study of employment growth and variations across US states, Mila and McGuire (1992) found that the cyclical sensitivity of employment within a given industry differed significantly from one state to another. This is also the case for the UK regions, illustrated for example, by comparing the East of England and the North West (Figure 9). For virtually every sector, relative employment growth in the East of England

Figure 9: Sectoral Employment Growth Differentials (Relative to National Sectoral Rates), East of England and North West Compared, 1972-2014
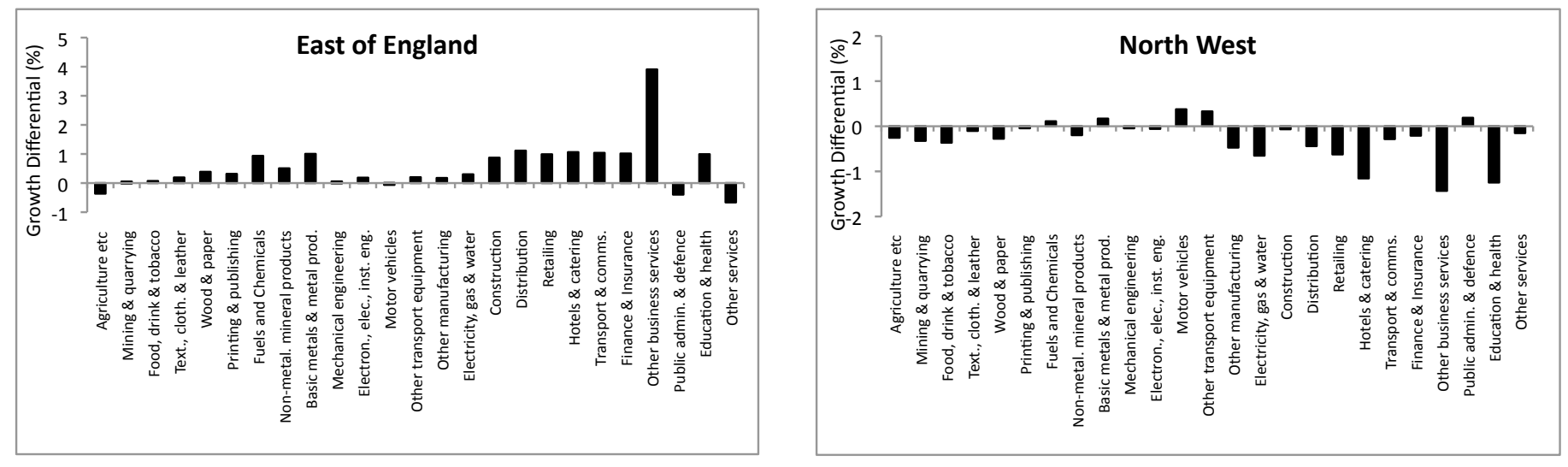
region (one of the more resilient) has been greater than that nationally, whereas in the case of the North West (a much less resilient region), virtually every sector has underperformed in employment growth. What this suggests is the need to explain why it is that the same sector can perform quite differently in different regions, for it would seem that such differences - and their evolutions over time - can exert a significant influence over how regions react to successive economic cycles. What this certainly points to is the fact that to understand regional resilience to recessionary and other shocks we need to explore the various other sets of factors and determinants, other than just industrial structure, summarised in Figure 6.

\section{Exploring the Region-Specific Component of Resilience}

Numerous factors may account for why firms in a given sector in a given region grow faster (or slower) than their counterparts in the same sector nationally: for example, differences in particular market segments they supply, in levels of capacity utilization, their technological sophistication and efficiency, the functional nature of the firms involved (eg whether head offices or back offices, whether branch plants or principal facilities), in their wage cost structures, profitability and financial viability, the skill make-up of their labour forces, and in their productivity and competitiveness more generally. As we have argued above, with the major exception of London, these differences in regional 'competitiveness' effects, particularly in periods of recovery, seem to show a reasonably persistent regional pattern. A full answer must wait for more in-depth research but we can suggest several possible sources for this persistence. The first is that many of these effects are likely to reflect the outcome of firm interactions and the cumulative build-up of stronger service markets in some cities and regions. Inter-firm interdependencies are as significant in the post-industrial economy as they were in the industrial past, as many service industries are heavily influenced by, and integrated in, direct and indirect relationships with other industries, both services and non-services. There are strong spatial divisions of labour within many producer and business service sectors because of the way in which firms are shaped by the nature of demand and whether their markets are local, regional or global (ie by the extent and orientation of the tradable base), and to what degree their clients are based in public or private sectors. Producer service firms serving global and international clients are quite different creatures from those servicing local markets. Similarly, the growth of consumer service firms reflects, and amplifies, differences in rates of growth in income, prosperity and housing wealth. Such factors appear to partly explain why it is that of all the former large manufacturing centres, London since 1993 has best been able to dramatically escape the legacy of deindustrialisation (Martin, 2013). In addition, however, the persistence of these regional effects also suggests that firm level differences may well have become heavily inter-locked with institutional differences between the regions. 
As we noted in Section 4, what we might call the 'institutional context' of regional economic growth and development could well be important to the processes underlying resilience. By 'institutional context' we are referring to the sets of established practices, conventions and policies that influence firm behaviour, the operation of the financial system and labour markets, and the nature of policy interventions, all of which regulate and govern economic activity, and hence thereby may influence the resilience of individual regions, cities and localities to major recessionary and other shocks. Such influences operate at several scales simultaneously. National-scale institutions and policies typically produce uneven regional effects and outcomes, while at the same time there is some evidence of differences between institutions between different regions.

There are several such institutions and institutional arrangements that may condition (positively or negatively) the adaptive strategies that firms pursue in response to deep recessionary downturns. Even national or nation-wide institutional forms and conditions can have spatially differentiated impacts on economic activity. One such is the national innovation environment or regime. There are strong grounds for believing that innovative firms are much more likely to be more competitive and adaptive in the face of economic shocks. So one possible source of the 'regional-specific or competitiveness' component of resilience identified in Section 4 may be differences in firm innovativeness across regions. While the UK economy as a whole shows what some regard as an 'institutionalized' weakness in the development of innovative, export-focused small and medium sized firms, there is considerable evidence that the problem is more severe in the northern regions. The concentration of $\mathrm{R}$ and $\mathrm{D}$ expenditure and innovative activities in the South East is pronounced and well-known (see Cantwell and Iammarino, 2000; Roper et al, 2015). Knowledge spillovers from innovation are bound to be greater in such localities and may differentiate firm growth within sectors. Institutional forces plus more informal cultural norms and aspirations also combine to produce stubborn regional differences in entrepreneurial activity, as suggested by lower new firm start-up rates in the northern regions of the country (Huggins and Williams, 2011). Moreover, the consequences of entrepreneurialism for growth depend on the institutional support provided to start-ups and on the degree to which entrepreneurs are assimilated into regional knowledge networks and become part of supportive 'ecosystems' (ibid). Regional firm-based competitiveness effects may thus to some extent reflect whether localities and regions provide a supportive entrepreneurial and innovation 'ecosystem' or knowledge infrastructure that allows firms to develop, absorb and share knowledge. There are many key questions concerning whether the reliance on foreign direct investment in former industrial regions has allowed and promoted the growth of such ecosystems. Significant regional differences in their extent and coherence are likely to prove more significant as firms seek to grow in periods of expansion and recovery. 
Certainly, there are indications of regional differences in the quality of institutional support to firm growth and expansion. Small and medium sized firms, for example, may be crucially dependent on credit in order to remain viable during difficult economic times and to be able to 'ride out' deep recessions. The spatial organization and lending strategies of the banking system may thus be important. For instance, the UK's banking and venture capital system has remained heavily concentrated London and the South East and has created unbalanced reinforcing logics between the demand for and supply of development finance (Martin et al, 2005). Both bank lending to, and equity investment in, small and medium companies have been disproportionately focused in London and the South East (British Business Bank, 2014; Klagge, Martin and Sunley, 2015). It is entirely plausible that spatial asymmetries in capital markets become more of a constraint in upturns, and thereby reinforce regional 'competitiveness' effects. Indeed, as Degryse et al (2015) have shown in their detailed analysis of bank lending to manufacturing SMEs in the British regions over 2004-2011, the thin and highly centralised branch banking system in Britain has worked to expose the more peripheral regions to substantial variation in credit supply over the economic cycle (see also Zhao and Jones-Evans, 2015). In their view, functional distance between bank branches and their institutional headquarters was a key factor in SME access to finance during the recession. Their findings indicate that "during and after the financial crisis, the distance between bank branches and headquarters plays a significant role, suggesting the presence of a 'flight to headquarters' effect of banks in rebalancing their loan portfolio across different local markets in the post crisis period” (op. cit. p.28). This suggests an important avenue for further research into how geographical differences in local firms' access to finance may influence the regional pattern of economic resilience.

Another aspect of the 'institutional context' that can condition firms' responses to deep recessionary downturns relates to the labour market. The labour market is highly structured and regulated institutionally. At a basic level, Krugman (2006) argues that educational institutions form a key part of what he calls the 'fundamentals' that shape the performance, prosperity and adaptability of a region's economy. A well-qualified and skilled local workforce not only influences how firms utilize labour, but also provides the local economy as a whole with greater scope for adapting out of major crises. Segmented labour market theory suggests that firms try to hold on to skilled personnel at times of depressed demand and cyclical downturn, since such workers are not only key to productivity but if laid off may be difficult to recruit when economic circumstances improve. There are significant differences in the educational-institutional bases of the UK regions, which differences influence the supply and movement of educated and skilled labour. For example, the proportion of working age adults with no qualifications is about a third higher in traditional northern manufacturing regions than it is in London and the South East (ONS, 2014). The supply of skilled and educated labour varies markedly by region so that while 40 percent of London's population is educated to degree level the figure for the North East is just 24 percent (Wright et al, 2010). Moreover, these differences 
appear to have widened over the past thirty years with regions with the highest supply of skilled workers showing the fastest trend rates of growth in employment (ibid). It is well known that there is a positive relationship between the skill endowment of a region's workforce and the productivity of its firms, and the higher the productivity of local firms the more resilient they are likely to be.

It also tends to be the most educated and skilled individuals that are the most geographically mobile. We might expect a net movement of workers out of those regions worst affected by major economic downturns, although the ability to move may itself be dampened at times of nation-wide economic recession. The elasticity of inter-regional migration of (especially educated and skilled) workers with respect to the regional impact of recession is thus an interesting issue. It too is shaped by institutional factors, such as the way that the housing market and housing finance system operate, with the latter being highly influenced by interest rates, which in turn are shaped by Bank rate, itself a key national policy lever. In the UK, historically there has tended to be a net outward migration

\section{Figure 10: Net Inter-Regional Migration between the North and South of the UK}

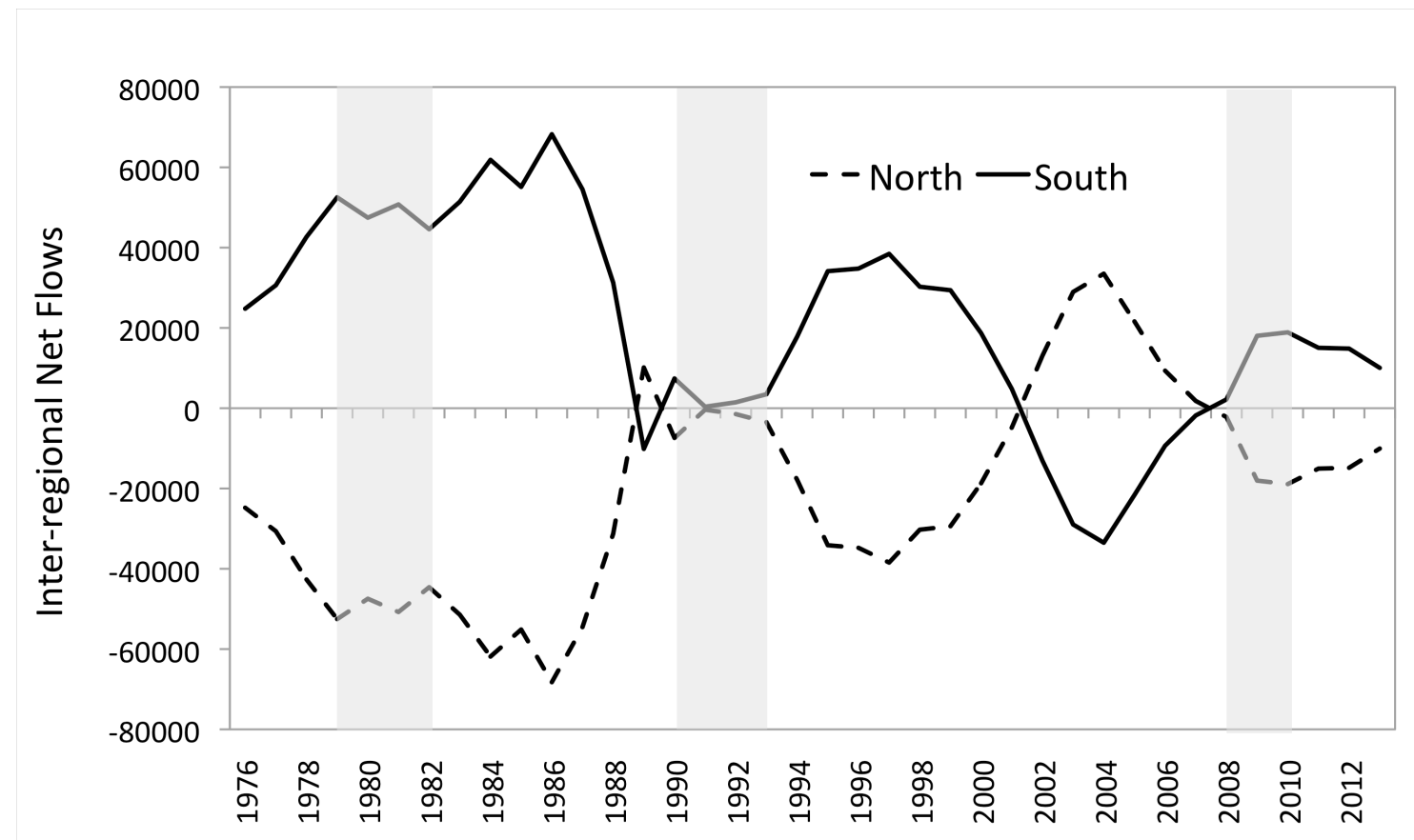

Note: South - London, South East, South West, East of England, East Midlands;

North - West Midlands, Yorkshire-Humberside, North East, North West, Wales, Scotland and Northern Ireland. National recessionary downturns shown shaded.

Source of data: Data based on national health registration records, and kindly supplied by Professor Champion, Newcastle University. It should be noted that the data refer to the movement of residents within the UK, and do not include overseas migration (in or out).

from the slower growing and lower recoverability northern regions of the UK into the faster growing and higher recoverability southern regions (Figure 10). On the one side, this 
net drift southwards can be argued to have kept northern unemployment lower than it might otherwise have been; on the other side, it is likely to have been the more skilled and enterprising workers that have migrated southwards, thereby depriving the northern regions of more productive human capital (Rowthorn, 2010). However, while this movement has been distinctly cyclical in nature, it is not straightforwardly correlated with the succession of economic recessions and recoveries. Further, the scale of the net movement has steadily declined over time. In fact, the net movement from the north into the south seems to have declined in the latter half of each recovery phase of the economic cycle, and may well reflect the rapid rise in house prices in the south (London and the South East especially) that has characterized these periods. The widening gap in house prices between the south and north of the country has been largely attributed to a serious lack of housing supply in the former, which in turn is argued by some to be caused by the UK's national system of restrictive planning regulations that prevent local authorities from allowing new housing developments in 'green belt' areas. So again, institutional factors can shape the underlying resilience of regions and localities, and hence how they respond to and recover from major economic shocks

Yet another possible determinant of regional resilience to recessions that links to institutional arrangements is regional policy. Post-war regional policy in the UK, at least up the end of the 1970s, was primarily focused on encouraging manufacturing industries to expand in or relocate to the more northern areas of the country, with controls on office space also being used in London and other parts of the South East. The precise impact and implications of this policy are open to debate. While it has been estimated that perhaps as many as 500,000 jobs were created in the northern regions of the UK by means of regional policy over the 1960s, 1970s and early-1980s, many of these jobs were in branch plants which then proved prone to closure when faced with the winds of economic slowdown and recession, while at the same time the growth of London and the South East was possibly held back. Furthermore, regional policy rarely had the specific aim of diversifying the economic base of the industrial northern regions, and may in fact have served to prop up industries and firms that were not competitive. How regional policy has impacted on the economic resilience of the UK regions is an unexplored subject.

More generally, how the various forms of public spending, from fiscal and monetary measures (such as interest rate policy - a key measure used in the UK to stimulate recovery from the recession of 2008-2010), to social welfare spending to investment in infrastructure, impact across regions may well play a significant role in determining the resilience of regions to recessions. We know little, for example, about how far (and with what long-run as well as short-run consequences) the automatic inter-regional redistributive mechanisms associated with the UK's national tax and benefit systems shapes the reaction of the country's regions to shocks. Differences across regions in the severity of a common shock initiates automatic fiscal transfers between regions (from 
lower unemployment regions to higher unemployment ones), but whether such transfers aid recovery in the worst-hit regions or whether they give rise to hysteretic effects (leaving a higher proportion of the local labour force as long term unemployed dependent on benefits) is unknown.

A government's overall fiscal stance in response to a deep recession may also have disparate regional consequences. Historically, UK Governments adopted a basically Keynesian approach to managing economic cycles by relaxing fiscal policy and increasing public spending in downturns. How such countercyclical policy impacted across the regions remains an under-researched topic. In the recent recession, however, Government policy has been quite different, involving the imposition of substantial cuts in public spending. This fiscal austerity programme, still ongoing, has had quite uneven geographical effects, falling most heavily on those regions that had a higher dependency on public sector employment, which included most of the northern regions. Thus between 2008 and 2014, the North East lost 19 percent of its public sector jobs, YorkshireHumberside 12.6 percent, the West Midlands 12.4 percent, and Wales 9.5 percent. This contrasts with London, which lost only 3 percent (SPERI, 2015). This uneven geography of public employment decline, which will in all likelihood be permanent (and there are more cuts to come), has almost certainly served to slow the relative recovery of the northern regions from the 2008-10 recession compared to their southern counterparts. Meanwhile, while these cuts have been imposed, London has benefited from one of the biggest ever public infrastructural projects in Europe, the $£ 15$ bn Cross Rail, a new 42km east-west rail link, much of it tunneled under the city itself. There can be little doubt that this project has in effect served, in part at least, as a specific form of regional policy to the benefit largely of London and its environs.

Clearly, in thinking about the role of region-specific non-structural 'competitiveness' effects in the development of regional resilience, the research agenda is potentially extensive. The natural inclination is to search for factors and determinants that are themselves regionally-specific. Krugman (2005) calls such factors and conditions 'fundamentals', to distinguish them from influences associated with the particular structural form of economic development and specialisation in a region. It seems inescapable that any detailed analysis of the nature and role of such region-specific 'fundamentals' in determining resilience to recessions (and other shocks) will require indepth (comparative) case study research. But it is also the case that national-level, ostensibly non-spatial processes and policies can have quite different impacts on the pattern and process of regional development, and hence on regional resilience. Thus a case study approach would also need to examine how such national factors play out in specific regional contexts. 


\section{Conclusions and Directions for Further Research}

Our aim in this paper has been to explore how the last four economic cycles of recessions and subsequent recoveries have impacted across the UK regions. Not only is it clear that the economic cycle is far from dead, it is also evident that the geography of each recession and subsequent recovery has varied from one cycle to the next. There are some similarities and broad patterns that recur over time, in that overall the southern and eastern regions of the country have tended to be more resilient, apparently able to 'bounce back' strongly even if badly hit by a recession. There are also significant differences across and within regions in both their resistance to and recoverability from successive recessionary shocks. Of particular interest is the fact that, up until the most recent cycle, regional differences in resistance and recovery appear to have narrowed somewhat: the regions seem to have been converging on a broadly similar pattern of cyclical behaviour. Whether the reassertion of regional differences in recoverability thus far observed in the current cycle marks a reversal of that trend, or is a temporary departure, is as yet unclear, not least because this part of the cycle is not complete.

The findings in the paper raise three key issues that require further research. The first concerns the role of economic structure. While economic structure has had some influence on how particular regions have responded to the last four economic cycles, its impact has not been consistent, either geographically or temporally. Furthermore, the influence of economic structure appears to have declined over time, especially in the recessionary phases of each successive cycle. Of course, it could be argued that the level of industrial disaggregation employed here masks important structural differences across the regions, and that a more detailed analysis might yield different results. In addition, it may well be that it is not economic structure per se that matters, but the linkages and interactions between industries within and across regions, an issue we have not been able to investigate here. In this context, writing some thirty years ago, Massey (1984) argued that the spatial division of labour across the UK was being transformed, from a regional pattern of sectoral specialisation that had underpinned the industrial era of national economic development, to a regional system of functional specialisation, in which firms in the same industry perform different functions in different regions (such as research in one region and production in another; or head office functions in one region and back office activities in another). This points to a relational view of regional economies, and may mean that the same industry behaves differently in different regions in response to major recessionary downturns.

But, second, the fact that the role of 'region-specific' factors appears to be so prominent requires considerably more attention. The size of this effect suggests that it is not simply an outcome of the level of economic disaggregation employed here. In theory, this effect has to do with the conditions found in a region that influence how its industries 
perform compared to their counterparts nationally. The range of possible relevant 'regionspecific' factors is extensive. The relative importance of small enterprises might be one such; the degree of foreign ownership of local industry another; the nature and geographical distribution of supply chains yet another; even the legacy of inherited local labour market conditions and institutions might be still another. The size of a region in terms of local 'home market' effects may also play a role. Alternatively, the export orientation and dependence of a region may be a key factor (serving particularly buoyant overseas market segments may act as an important buffer against, and a source of recovery advantage, from recessionary downturns). Or it could be that there are important functional economic differences within sectors across regions. And then there is role of institutional conditions and effects, both local and national. We simply do not know how these and other locally-specific 'competitive' effects influence the spatial anatomy of economic cycles .

Third, within the limitations of the available data used here, the findings in this paper suggest that long-run trends and shifts in regional economies, both in their industrial structures and in locally-specific conditions and factors affecting economic performance across sectors, are key influences on the evolving geographies of resistance to and recovery from recessions. Cyclical dynamics are embedded within - are both shaped by and help shape - long-term regional developmental paths. Put another way, recessions and recoveries are part of the evolving dynamics of regional growth, not events superimposed upon some exogenously given, predetermined trajectory to which a region's economy automatically returns. The implication is that, when compared over any extended period of time, regional responses to recession and recovery are almost certain to vary from one cycle to the next, and that to understand such variations requires not just an explication of the nature of each recession-recovery cycle itself, but also how the impact of that cycle is both configured by and in turn reconfigures each region's mode of growth. The study of regional cyclical resistance and recoverability is thus integral to understanding long-run patterns of uneven regional development.

\section{Appendix}

The employment data used in the analysis for this paper were supplied by Cambridge Econometrics, and refer to the Standard or Governments Office Regions (which are also the NUTS1 regions used by the European Commission). Data for 25 industries were used, based on the 2-digit industrial level, aggregated in certain cases as shown in the Table below.

\section{Industry Name}

\section{2-Digit Industry Codes}

(SIC 2003) 


$\begin{array}{ll}\text { Agriculture etc } & 01,02,05 \\ \text { Mining \& Quarrying } & 10,11,12,13,14 \\ \text { Food, drink \& tobacco } & 15,16 \\ \text { Textiles, clothing \& leather } & 17,18,19 \\ \text { Wood \& paper } & 20,21 \\ \text { Printing \& publishing } & 22 \\ \text { Fuels and Chemicals } & 23,24, \\ \text { Rubber, plastics and non-metal products } & 25,26 \\ \text { Basic metals \& metal products } & 27 \\ \text { Mechanical engineering } & 28,29 \\ \text { Electron., elec., inst. Engineering } & 30,31,32,33 \\ \text { Motor vehicles } & 34 \\ \text { Other transport equipment } & 35 \\ \text { Other manufacturing } & 36,37 \\ \text { Electricity, gas \& water } & 40,41 \\ \text { Construction } & 45 \\ \text { Distribution } & 50,51 \\ \text { Retailing } & 52 \\ \text { Hotels \& catering } & 53 \\ \text { Transport \& communications } & 60,61,62,63,64 \\ \text { Banking, finance, insurance } & 65,66 \\ \text { Other business services } & 67,68,70,71,72,73,74 \\ \text { Public admin. \& defence } & 75 \\ \text { Education \& health } & 80,85 \\ \text { Other services } & 90,91,92,93,95,96,97,99\end{array}$

\section{References}

Artige, L. and van Neuss, L. (2014) A new shift-share method, Growth and Change, DOI: 10.1111 /grow. 12065

Artis, M. Dreger, C. and Kholodilin, K. (2009) Common and spatial drivers in regional business cycles, Discussion Paper 859, Deutsches Institut fur Wirtschaftsforschung, Berlin.

Barf, R.A. and Knight, P.L. (1988) Dynamic shift-share analysis, Growth and Change, 19, pp, 1-10.

Barrios, S., Brülhart, M., Eliot, R.J.R and Sensier, M. S. (2003) A tale of two cycles: cofluctuations between U.K. regions and the Euro zone, Manchester School, 71, pp. 265-292

Barrios, S. and de Lucio J. J. (2003) Economic integration and regional business cycles: Evidence from the Iberian regions, Oxford Bulletin of Economics and Statistics, 65, pp.497-515.

Bassett, K. and Haggett, P. (1971) Towards a short-term forecasting model of cyclical 
behaviour in a regional system of cities, in Chisholm, M. (Ed) Regional Forecasting, London: Butterworths, pp. 389-413.

Bayoumi, T. and Eichengreen, B. (1993) Shocking aspects of European monetary integration, in Torres, F. and Giavazzi, F. (Eds) Adjustment and Growth in the European Union, Cambridge: Cambridge University Press, pp. 193-229.

Belke, A. and Heine, J.M. (2006), Specialisation patterns and the synchronicity of regional employment cycles in Europe, International Economics and Economic Policy, 3, pp. 91-104.

Beyers, W. (2013) The Great Recession and state unemployment trends, Economic Development Quarterly, 27, pp. 114-123.

Bierbaumer-Polly, J. (2012) Regional and Sectoral Business Cycles: Key Features for the Austrian Economy, Austrian Institute of Economic Research (WIFO), Vienna, Austria.

Boschma, R. (2015) Towards an evolutionary perspective on regional resilience, Regional Studies, 49, 1, pp. 733-752.

Borts, G. (1960) Regional cycles of manufacturing employment in the US, 1914-1953, Journal of the American Statistical Association, 55, pp. 151-211.

Brechling, F. (1967) Trends and cycles in British regional unemployment, Oxford Economic Papers, 19, pp. 1-21.

British Business Bank (2014) Small Business Finance Markets, London: BBB.

Briguglio, L. (2004) Economic Vulnerability and Resilience: Concepts and Measurements, In Briguglio, L. and Kisanga, E.J. (Eds), Economic Vulnerability and Resilience of Small States, Islands and Small States Institute and Commonwealth Secretariat.

Briguglio, L., Cordina, G., Bugeja, S. and Farrugia, N. (2009) Conceptualising and Measuring Economic Resilience, Mimeo, Economics Department, University of Malta.

Bristow, G. (2010) Resilient regions: re-'place'ing regional competitiveness, Cambridge Journal of Regions, Economy and Society, 3, 1, pp. 153-167.

Burns, A.F. and Mitchell, W.V. (1946) Measuring Business Cycles, Washington: National National Bureau of Economic Research Books.

Cambridge Journal of Regions, Economy and Society (2010) Special Issue on: The Resilient Region, 3, 1.

Cantwell, J. and Iammarino, S. (2000) Multinational corporations and the location of technological innovation in the UK regions, Regional Studies 34, 4, pp. 317-332.

Carlino, G. and Sill, K. (1996) Regional income trends: common trends and common cycles, Review of Economics and Statistics, 83, pp. 446-456.

Carlino, G. and Sill, K. (1997) Regional economies: separating trends from cycles, Federal Reserve Bank of Philadelphia Business Review, May/June, pp. 1-13. 
Champion, T. and Townsend A. (2013) Great Britain's second-order city regions in recessions, Environment and Planning A, 45, pp. 362-382.

Clark, T.E. (1998) Employment fluctuations in U.S. regions and industries: the roles of national, region-specific, and industry-specific shocks, Journal of Labor Economics, (16), pp. 202-29.

Clark, T.E. and Shin, K. (2000) The sources of fluctuations within and between countries, in Hess, G.D. and van Wincoop, E. (Eds) Intra-national Macro-economics, Cambridge: Cambridge University Press, pp. 189-220.

Conroy, M. (1975) Regional Economic Diversification, New York: Praeger.

Cross, R., McNamara, H. and Pokrovskii, A. (2009) Memory of recessions, Discussion Papers in Economics 10-09, Department of Economics, University of Strathclyde.

Davies, A. and Tonts, M., (2010) Economic Diversity and Regional Socio-Economic Performance, Geographical Research 48, pp. 223-234.

Degryse, H., Matthews, K and Zhao, T. (2015) SMES and access to bank credit: evidence on the regional propagation of the financial crisis in the UK, CESifo Working paper No. 5425, Centre for Economic Studies, Munich.

Dissart, J.C. (2003) Regional Economic Diversity and Regional Economic Stability: Research Results and Agenda, International Regional Science Review, 26, pp. 193204.

Domazlicky, B. (1980) Regional business cycles. A survey, Regional Science Perspectives, 10 , pp. 15-34.

Doran, J. and Fingelton, B. (2013) US Metropolitan Area Resilience: Insights from Dynamic Spatial Panel Estimation, Paper presented at the Annual Conference of the Regional Science Association International (British and Irish Section), University of Cambridge, August 22.

Duranton, G. and Puga, D. (1999) Diversity and specialisation in cities: Why, where and when does it matter? Research Papers in Environmental and Spatial Analysis No. 56, Department of Geography and Environment, London School of Economics.

Evans, R. and Karecha, J. (2013) Staying on Top: Why is Munich so Resilient and Successful? European Planning Studies, DOI:10.1080/09654313.2013.778958

Farhauer, O. and Kröll, A. (2012) Diversified Specialisation: Going One Step Beyond Regional Economics' Specialisation-Diversification Concept, Jahrbuch für Regional Wissenschaft, 32, 1, pp. 63-84.

Fatas, A. and Mihov, I. (2013) Recoveries, Working Paper 9551, Centre for Economic Policy Research, London School of Economics, London, UK.

Fingleton, B., Garretsen, H. and Martin, R.L. (2012) Recessionary shocks and regional employment: evidence on the resilience of UK regions, Journal of Regional Science, 52, pp. 109-133. 
Fingleton, B., Garretsen, H. and Martin, R.L. (2015) Shocking aspects of monetary union: The vulnerability of regions in Euroland, Journal of Economic Geography, 15, pp. 907-934.

Frenken, K., Van Oort, F.G., and Verburg, T. (2007) Related variety, unrelated variety and regional growth, Regional Studies, 41, pp. 685-697.

Frankel, J.A. and Rose, A.K. (1998) The endogeneity of the optimum currency area criteria, European Economic Review, 108, pp. 1009-1025.

Friedman, M. (1988) The 'plucking model' of business fluctuations revisited, Economic Enquiry, 31, pp. 171-177.

Garcia-Mila, T. and McGuire, T, J. (1993) Regional economic performance and industrial composition, City-scape, 1, pp. 95-115

Gardner, N. (1987) Decade of Discontent: The Changing British Economy Since 1973, Oxford: Blackwell.

Gertler, M. (2010) Rules of the game: The place of institutions in regional economic change, Regional Studies 44, pp. 1-15.

Haggett, P. (1971) Leads and lags in inter-regional systems: a study of cyclic fluctuations in the South West economy, in Chisholm, M. and Manners,G. (Eds) Spatial Policy Problems of the British economy, Cambridge: Cambridge University Press, pp. 6995 .

Harris, C.P. and Thirlwall, A.P. (1969) Inter-regional variations in cyclical sensitivity to unemployment in the UK, Bulletin of the Oxford Institute of Economic Statistics, 30, pp.

Harding D. and A.R. Pagan (2002), Dissecting the cycle: a methodological investigation, Journal of Monetary Economics, 49 (2), pp. 365-381.

Hassink, R. (2010) Regional Resilience: A Promising Concept to Explain Differences in Regional Economic Adaptability? Cambridge Journal of Regions, Economy and Society, 3, 1, pp. 45-58.

Hausmann, R. Hidalgo, C.A., Bustos, S., Coscia, M., Simeos, A. and Yildirim, M.A. (2013) The Atlas of Economic Complexity: Mapping Paths to Prosperity, Cambridge, Mass: MIT Press.

Hayashida, M. and Hewings, G. J.D. (2009) Regional business cycles in Japan, International Regional Science Review, 32, pp. 119-147.

Hornstein, A. (2000) The business cycle and industry co-movements, Economic Quarterly, 86, pp. 27-48.

Huggins, R. and Williams, N. (2011) Entrepreneurship and regional competitiveness: The role and progression of policy, Entrepreneurship and Regional Development 23, pp. 907-932.

Jackman, R. and Savouri, S. (1999) Has Britain solved the 'regional problem'? In Gregg, P. and Wadsworth, J. (Eds) The State of Working Britain, Manchester: Manchester University Press, pp. 
Jeffrey, D. (1974) Regional fluctuations in unemployment within the US economic system - a study of the spatial impact of short-term economic change, Economic Geography, 5o, pp. 111-123.

Jeffrey, D., Cassetti. E. and King, L. (1969) Economic fluctuations in a multiregion setting, Journal of Regional Science, 9, pp. 397-404.

Jones, P. (2012) Job creation and regional change under New Labour: a shift-share analysis, Environment and Planning, A, 44, pp. 1348-1362.

Kim, S. (1995) Expansion of markets and the geographic distribution of economic activities: the trends in US regional manufacturing structure, 1860-1987, Quarterly Journal of Economics, 110, pp. 881-908.

Kitano, H. (2004) Biological Robustness, Nature Reviews - Genetics 5, pp 826-837.

Klagge, B., Martin, R.L. and Sunley, P.J. (2015) The spatial structure of the financial system and the funding of regional business: a comparison of Britain and Germany, In Martin, R.L. and Pollard. (Eds) Handbook of the Geographies of Money and Finance, Chichester: Edward Elgar.

Krugman, P. (1993) Lessons of Massachusetts for EMU, in Torres, F. and Giavazzi, F. (Eds) Adjustment and Growth in the European Union, Cambridge: Cambridge University Press, pp. 241-261.

Krugman, P. (1996) Pop Internationalism, Cambridge, Mass: MIT Press.

Krugman, P. (2006) Second winds for industrial regions? In Coyle, D., Alexander, W. and Ashcroft, B. (Eds) New Wealth for Old Nations, Princeton, New Jersey, Princeton University Press, pp. 35-47.

Lilien, D.M. (1982) Sectoral shifts and cyclical unemployment, Journal of Political Economy, 90, 4, pp. 777-793.

Martin, R.L. (2004) The contemporary debate over the North-South Divide: images, and realities of regional inequality in late-twentieth century Britain, in Baker, A.R.H. and Billinge, M.D. (Eds) Geographies of England: The North-South Divide - Imagined and Material, Cambridge: Cambridge University Press, pp. 15-43.

Martin, R.L. (2010) Uneven regional growth: the geographies of boom and bust, Chapter 3 in Coe, N. and Jones, A. (Eds) The Economic Geography of the UK, London, Sage, pp. 29-46.

Martin, R.L. (2012) Regional economic resilience, hysteresis and recessionary shocks, Journal of Economic Geography, 12, pp. 1-32.

Martin, R.L. (2013) London's economy: from resurgence to recession to rebalancing, in Tewdwr-Jones, M., Phelps, N. and Freestone, R. (Eds) The Planning Imagination: Peter Hall and the Study of Urban and Regional Planning, London: Routledge, pp. 65-84.

Martin, R., Berndt, C., Klagge, B. and Sunley, P. (2005) Spatial proximity effects and regional equity gaps in the venture capital market: evidence from Germany and the UK, Environment and Planning A, 37, pp. 1207-1231. 
Martin, R.L., Gardiner, B. and Tyler, P. (2014) The Evolving Economic Performance of UK Cities: City Growth Patterns, 1981-2011, Future of Cities Foresight Working Paper 5, UK Government Office for Science, London: Department of Business, Innovations and Skills.

Martin, R.L., and Sunley, P. J. (2015) On the notion of regional economic resilience: conceptualization and explanation, Journal of Economic Geography, 15, pp. 1-42

Massey, D. (1984) Spatial Divisions of Labour: Social Structures and the Geography of Production, Basingstoke: Macmillan

Montoya, L.A. and De Haan, J. (2008) Regional business cycle synchronization in Europe? International Economics and Economic Policy, 5, pp. 123-137.

Neff, P. (1949) Interregional cyclical differentials: causes, measurement and significance, American Economic Review, 39, pp. 105-119.

Ohguz, S. and Knight, J. (2010) Regional economic indicators: A focus on regional gross value added using shift-share analysis, Economic and Labour Market Review, 4, pp. 74-87.

ONS (2014) Local Area Analysis of Qualifications Across England and Wales, ONS 7 March 2014.

Ormerod, P. (2008) Resilience After Local Shocks, Applied Economic Letters, May (http://dx.doi.org/10.1080/13504850801964331)

Owyang, M.T., Piger, J., Wall, H.J. (2005): Business cycle phases in US states, Review of Economics and Statistics, 87, pp. 604-616.

Panteladis, I. and Tsiapa, M. (2011) Business cycle synchronisation in the Greek regions, Journal of Urban and Regional Analysis, 3, pp. 143-158.

Partridge, M.D., Rickman, D.S. (2005) Regional cyclical asymmetries in an optimal currency area: An analysis using US State data, Oxford Economic Papers, 57, pp. 373-397.

Robson, M. (2009) Structural change, speciaisation and regional labour markets performance: evidence for the UK, Applied Economics, 41, pp. 275-293.

Rodriguez-Pose, A. (2013) Do institutions matter for regional development?, Regional Studies 47, 7, pp. 1034-1047.

Roper, S., Love, J. and Bonner, K. (2015) Benchmarking Local Innovation, Enterprise Research Centre.

Rose, A.and Krausmann, K. (2013) An Economic Framework for the Development of a Resilience Index for Business Recovery, International Journal of Disaster Risk Reduction, 5, pp. 73-83.

Rowthorn, R.E. (2010) Combined and uneven development: reflections on the NorthSouth Divide, Spatial Economic Analysis, 5, pp. 355-362.

Scott, M. (2013) Resilience: a conceptual lens for rural studies? Geography Compass, 7, pp. 597-610. 
Setterfield, M. (1997) Rapid Growth and Relative Decline: Modelling Macroeconomic Dynamics with Hysteresis, Basingstoke: Macmillan.

Sherwood-Call, C. (1990) Assessing regional economic stability: a portfolio approach. Economic Review of the Federal Reserve Bank of San Francisco. Winter: pp. 17-26.

Siegel, P.B., Alwang, J. and Johnson, T,G. (1994) Toward an Improved Portfolio Variance Measure of Regional Economic Stability, Review of Regional Studies, 24, pp. 71-86.

Siegel, P.B., Alwang, J. and Johnson, T,G. (1995) A Structural Decomposition of Regional Economic Stability: A Conceptual Framework, Journal of Regional Science, 35, pp. 457-470

Simmie J. and Martin, R. (2010) The Economic Resilience of Regions: Towards an Evolutionary Approach, Cambridge Journal of Regions, Economy and Society 3, 1, pp. 27-43.

SPERI (2015) Public and Private Sector Employment across the UK since the Financial Crisis, British Political Economy Brief No. 10, Sheffield Political Economy Research Institute.

Stock, J.H. and Watson, M.W. (2002) Has the business cycle changed, and why? In Gertler, M. and Rogoff, K. (Eds) NBER Macroeconomics Annual, 17, pp. 159-218.

Stock, J.H. and Watson, M.W. (2003) Has the business cycle changed: evidence and explanation, Kansas City Federal Reserve Bank Symposium, pp. 9-56.

Storper, M. (2013) Keys to the City, Princeton: Princeton University Press.

Storper, M., Kemeny, T., Makarem. N. and Osman, T. (2015) The Rise and Fall of Urban Economies: Lessons from San Francisco and Los Angeles, Stanford: Stanford University Press.

Tondl, G., Traistaru-Siedschlag, I. (2006) Regional growth cycle synchronisation within the Euro Area, Working Paper 173, Economic and Social Research Institute, Dublin.

Townsend, A. and Champion, T. (2014) The impact of recession on city regions: The British experience, 2008-2013, Local Economy online.

Van Duijn, J. (1973) An Inter-Regional Model of Economic Fluctuations, Lexington, Mss: Lexington Books.

Vining, R. (1945) Regional Variations in cyclical variation viewed as a frequency distribution, Econometrica, 13, pp. 182-213.

Vining, R. (1946a) Location of industry and regional patterns of business cycle behaviour, American Economic Review, 39, pp. 89-104.

Vining, R. (1946b) The region as a concept in business cycle analysis, Econometrica, 14, pp. 201-218.

Whitacre, J.M. (2012) Biological robustness: paradigms, mechanisms and systems principles, Frontiers in Genetics, 3, Article 67, pp. 1-3.

Wright, J., Brinkley, I. and Clayton, N. (2010) Employability and Skills in the UK: Redefining the Debate, London: The Work Foundation. 
Zarnowitz, V. and Ozyildirim, A. (2006) Time series decomposition and measurement of cycles, trends and growth cycles, Journal of Monetary Economics, 53, pp.17171739.

Zhao, T. and Jones-Evans, D. (2015) SMEs, banks and the spatial differentiation of access to finance in the UK, Mimeo, Bristol Business School, Bristol University. 